Spring 2006

\title{
Symbolic interaction theory and architecture
}

\author{
Ronald W. Smith \\ University of Nevada Las Vegas, ron.smith@unlv.edu \\ Valerie Bugni \\ University of Nevada Las Vegas
}

Follow this and additional works at: https://digitalscholarship.unlv.edu/sociology_pubs

Part of the Environmental Design Commons, and the Place and Environment Commons

\section{Repository Citation}

Smith, R. W., Bugni, V. (2006). Symbolic interaction theory and architecture. Symbolic Interaction, 29(2), University of California Press.

https://digitalscholarship.unlv.edu/sociology_pubs/5

This Preprint is protected by copyright and/or related rights. It has been brought to you by Digital Scholarship@UNLV with permission from the rights-holder(s). You are free to use this Preprint in any way that is permitted by the copyright and related rights legislation that applies to your use. For other uses you need to obtain permission from the rights-holder(s) directly, unless additional rights are indicated by a Creative Commons license in the record and/or on the work itself.

This Preprint has been accepted for inclusion in Sociology Faculty Publications by an authorized administrator of Digital Scholarship@UNLV. For more information, please contact digitalscholarship@unlv.edu. 


\title{
Symbolic Interaction Theory and Architecture
}

\author{
Ronald W. Smith \\ University of Nevada, Las Vegas \\ Valerie Bugni \\ University of Nevada, Las Vegas
}

\begin{abstract}
Architectural sociology is receiving renewed attention but still remains a neglected area of investigation. As a major theoretical perspective within sociology, symbolic interaction helps us understand how the designed physical environment and the self are intertwined, with one potentially influencing and finding expression in the other; how architecture contains and communicates our shared symbols; and how we assign agency to some of our designed physical environment, which then invites in a different kind of self-reflection. This article discusses numerous instances of symbolic interaction theory-architecture connections, with applied examples showing how symbolic interactionists and architects can collaborate on projects to the benefit of each, and to the benefit of humanity.
\end{abstract}

Social beings are things as definitely as physical things are social. - George Herbert Mead

Architectural sociology is the study of how socio-cultural phenomena influence and are influenced by designed physical environment. Receiving renewed attention among both sociologists and architects (Broadbent 1980; Bugni and Smith 2002a, 2002b; Cranz 1989, 1998; Dubois 2001; Jones 1984; Smith and Bugni 2002; Sommer 1983; Zeisel 1975), this specialty area should be distinguished from the related field of environment sociology, which primarily focuses on the relationships between humans and their natural environments as opposed to their designed environments. Environmental sociologists examine the relationships among technology, urban development, population, capitalist industrialism and ecostructure, and the cultural and ideological shaping of our conceptions of the natural environment. (Catton and Dunlap 1978; Hannigan 1995; Murphy 2001). Despite the different emphases of the two areas, there are obvious and important overlaps between

Direct all correspondence to Ronald W. Smith, Department of Sociology, University of Nevada, Las Vegas, 4505 Maryland Parkway, Box 455033, Las Vegas, NV 89154-5033; e-mail: ron.smith@unlv.edu.

Symbolic Interaction, Vol. 29, Issue 2, pp. 123-155, ISSN 0195-6086, electronic ISSN 1533-8665.

(C) $\mathbf{2 0 0 6}$ by the Society for the Study of Symbolic Interaction. All rights reserved. Please direct all requests for permission to photocopy or reproduce article content through the University of California Press's Rights and Permissions website, at http://www.ucpress.edu/journals/rights.htm. 
architectural sociology and environmental sociology; for example, both seek to understand and contribute solutions to the ecological challenges facing urban design.

For our purposes, we define architecture to include forms designed and built by specialists. These forms include buildings (e.g., houses, churches, hospitals, prisons, factories, office buildings, and recreational and sports complexes), bounded spaces (e.g., streets, plazas, communities, and office spaces), objects (e.g., monuments, shrines, landmarks, and furniture), and the many elements that are part of architectural design (e.g., shapes, size, location, openness, designed landscapes, boundaries, lighting, color, textures, and materials used) (Lawrence and Low 1990:454).

As one of the primary theoretical perspectives within sociology, symbolic interaction helps to explain fundamental connections between architecture and human thought, emotions, and conduct. We propose that symbolic interaction theory contributes in three fundamental ways to our understanding of architecture:

1. The perspective emphasizes that designed physical environments and the self potentially influence and find expression in the other.

2. The theory informs us about how these designed physical environments contain and communicate our shared symbols and meanings (Bourdieu 1990; Giddens 1990; Gieryn 2000; Mead 1934).

3. Symbolic interaction theory reveals that this designed physical environment is not merely a backdrop for our behavior. Quite the contrary, because some designed physical buildings, places, and objects act as agents to shape our thoughts and actions; they invite self-reflection.

As aptly demonstrated by the on-going work of those participating in the International Visual Sociology Association and Society for Visual Anthropology, we believe that the visual component can contribute to the standard social sciences methodologies that rely on words and numbers, particularly for architectural sociology. In this article, therefore, as we discuss each contribution, we include illustrations, some visual and others described in our own words, to document important observations about symbolic interaction theory and architectural connections. We were drawn to the present topic by a fascination with both the pure and applied aspects of architectural sociology, and in the latter sense, have combined our efforts to work with architects on projects of social design, to collaborate with a school of architecture on cooperative grant proposals, and to teach architectural sociology courses to advanced university students majoring in architecture and sociology. Consistent with our applied interests, we conclude this article with a discussion of how symbolic interactionists and architects could collaborate to build designed forms to improve the human condition. 


\section{SYMBOLIC INTERACTION THEORY AND ARCHITECTURE: INTERSECTIONS}

Although they did not explicitly address the "self-architecture" connection, early symbolic interactionists did refer to the importance of non-human objects and places for the self. Much of George Simmel's discussion in his turn-of-the-century essay "The Metropolis and Mental Life," although he would not ordinarily be described as a symbolic interactionist, links self to space. This work became the starting point for the specialization of architectural sociology. Simmel focused on how the city with its intense social interaction, stimuli, and change had profound consequences for the individual. While the city enhances individual freedom, it also forces urban dwellers to become impersonal, reserved, indifferent, blasé, and calculating as a means of protection from over-stimulation (Simmel [1917] 1950). He viewed the self and the city, or self and place, as interdependent. Fractures in one's physical environment, so Simmel would argue, may cause a kind of alienation in one's very being, and those who feel isolation, normlessness, self-estrangement, and other forms of alienation will in turn alter their behaviors and performances in response to that environment (Ashley and Orenstein 1998:321-25).

During the late 1800s, psychologist William James, writing about the self, made reference to the importance of the physical environment (James 1890). He defines the "empirical self" as the many ways individuals think about themselves, and categorizes the empirical self into three categories: the "social self' refers to how we are regarded and recognized by others; the "spiritual self" refers to our inner self; and, most directly related to our discussion, the "material self" refers to the tangible objects, people, or places that influence the self (Brown 1998). His reference to objects and places could presumably be extended to include both architecture and the natural environment.

Sociologists of the day became equally fascinated with the subject of the self. Charles Horton Cooley (1902) wrote about the "looking-glass self," consisting of the imagination of another person's judgment of his or her appearance and the resulting self-feeling such as pride or mortification. As an interesting aside, Cooley uses a designed physical object (i.e., a looking glass) as a metaphor to convey the importance of others in self-assessment.

George Herbert Mead (1934) greatly extends the discussion about self and the physical environment. By discussing how inanimate objects and physical environment can constitute the generalized other, Mead provides an opportunity for the individual to carry on internal conversations in reference to an environment that has symbolic meanings and that influences the self. Mead comments on the role of objects and the reflexive nature of the self, "Any thing-any object or set of objects, whether animate or inanimate, human or animal, or merely physical-toward which he acts, or to which he responds, socially, is an element in what for him is the generalized other; by taking the attitudes of which toward himself he becomes conscious of himself as an object or individual, and thus develops a self or personality" (p. 154). 
Informed by Mead's work, E. Doyle McCarthy (1984:105-21) proposes four propositions that would logically extend to architecture: (1) physical objects play a central role in constituting and maintaining the self; (2) physical objects provide the self with a stable and familiar environment; (3) the acts of touching and grasping physical objects play a central role in our reality construction and maintenance; and (4) the self's relationship with the physical world is a social relationship.

Erving Goffman also discusses the link between self and physical environment. He defines "impression management" as the efforts of people to manage the impressions others form of them during performances within the "physical confines of a building or plant" (Goffman 1959:xi). The "front" region of the individual's performance defines the situation for the audience, and individuals may use the physical environment, including place and layout, furniture, decorations, and any other prop-like instruments, to "set the stage" for the front region.. Meanwhile, the "back region" is a guarded place where the individual creates the performance. Goffman also observes that certain performances may require the use of dual spatial regions. He states, "Thus, the private office of an executive is certainly the front region where his status in the organization is intensively expressed by means of the quality of his office furnishings. And yet it is here that he can take his jacket off, loosen his tie, keep a bottle of liquor handy, and act in a chummy and even boisterous way with fellow executives of his own rank" (p. 126). Goffman recognizes that impression management may involve use and manipulation of one's own physical environment, including both designed objects and designed places.

Herbert Blumer's (1969) definition of symbolic interaction focuses on the meanings we assign objects and that impact the self. He observes that there are three types of objects- "social objects" such as professors, students, and parents; "abstract objects" such as integrity, compassion, and loyalty; and most pertinent to our discussion, "physical objects" such as buildings, open spaces, desks, and hallways. Today, only a small number of symbolic interactionists continue to refine the discussion about designed forms and self. Among them, Milligan (1998, 2003) has studied self and emotions in the workplace (i.e., a coffee house). She finds that place attachment is based on nostalgic memories of past experiences in a physical setting and anticipations that such positive encounters might continue in the future. The essential point is that classical and, to a lesser extent, contemporary symbolic interaction scholarship reveals that the search for constructing, knowing, and performing the self often occurs in relation to designed physical environments.

As is the case with symbolic interactionists, architects, too, are no strangers to how the self can be revealed and expressed through designed environments and much of their thinking on the topic parallels that of symbolic interactionists. Chris Abel argues that the "architecture of identity now rivals the architecture of space... as one of the principal metaphors and themes in architectural discourse"(Abel 2000:141). Christopher Day (1990) believes architecture should be places of the soul where physical shapes, forms, spaces, and appearances provide a picture of reality that nourish human emotions and the self. In a now-classic description about 
the timeless way of building, Christopher Alexander (1979) maintains that buildings and communities only come alive as expressions of self. Finally, during the late $1800 \mathrm{~s}$, urban architect Frederick Law Olmsted guided thinking about the design of neighborhoods and major parks in New York (i.e., Central Park), Chicago, Montreal, Buffalo, Detroit, Cincinnati, and many other cities. In doing so he sought to plan cities and design public places and neighborhoods where the user could come to know and express an urban identity (Olmsted and Sutton 1979).

Turner (1976) and Appleyard (1979) contend that housing provides special expressions of personal and social identity. Cultural geographer and landscape architect Clare Cooper Marcus in House as a Mirror of Self (1995) extends the discussion on how people use their home environment and the objects therein to express who they are and what they would like to become. For example, she notes that children who construct a clubhouse have an early powerful experience of creativity and learn about the self as they mold their physical environment. Later as adults, we choose particular kinds of houses, furniture, decorations, colors, and fabrics to express self. We also choose the countryside, suburbia, small town, or city, and in doing so, we establish settlement identities. She reminds architects that deeper truths may be found about the self by examining the houses we designate as ours. The practical lesson to architects is that they should seek to build homes that allow for expression of self and not just houses that are devoid of personal meaning, such as the case with some of our present-day mass housing.

\section{ARCHITECTURE REFLECTS AND EXPRESSES SELF}

Architects obviously seek to design buildings and places that reflect and allow for expression of the self. Dramatic illustrations may be seen in Michael Arad and Peter Walker's winning design for the World Trade Center memorial entitled "Reflecting Absence" (Figure 1), as well as in the designs of other memorial finalists such as Norman Lee and Michael Lewis, whose interior design was entitled "Votives in Suspension" (Figure 2). The plan for the memorial, at the time of this writing, includes gardens, park plazas, reflecting pools, and a stone container of unidentified victims' remains. It is designed to reflect a collective sense of loss and absence, to honor those who lost their lives, and to provide a sense of hope and rebirth. The architects seek, among other goals, to define the World Trade Center site as a place where Americans can identify, and allow for expression of, self and the emotions experienced following the terrorist attacks of 9-11-01. Despite these design goals, many will form entirely different interpretions of the new architecture. Some may define the building as another capitalist object, with its huge expanse of business and hotel space; others may see a disconnect between self and the completed design because of claims that the final plan ignored some of the concerns of victims' families; and some locals may feel no self-attachment to the place because of the design's limited public space, its possible harmful impact on surrounding neighborhoods and small businesses, and the increased congestion caused by the memorial (Sorkin 2003). 
FIGURE 1.

Winning Design for the World Trade Center

Memorial: Reflecting Absence, by Michael Arad and Peter Walker

FIGURE 2.

Interior Design for the World Trade Center Memorial: Votives in Suspension, by Norman Lee and Michael Lewis
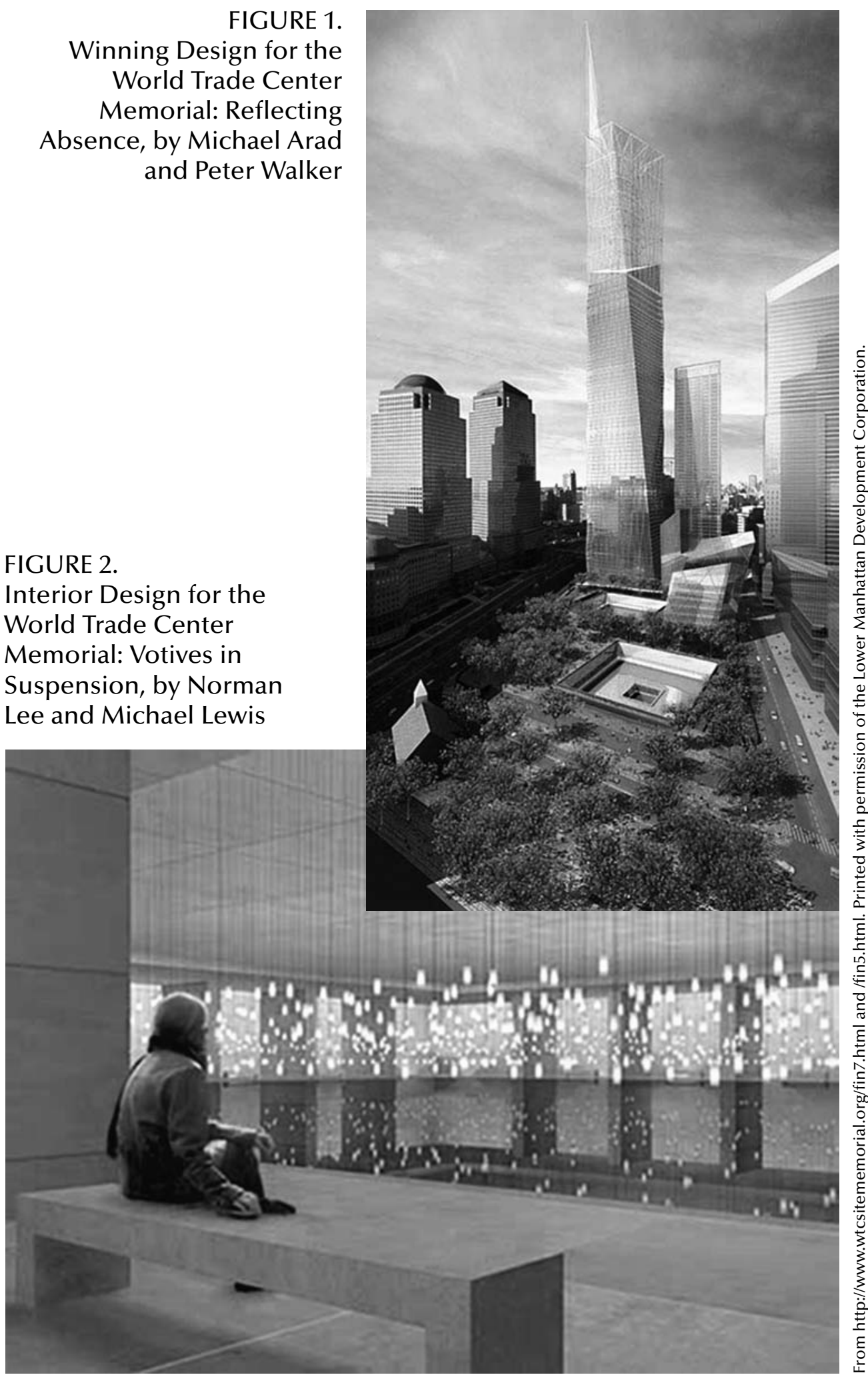
Architecture need not be elaborate or large in design to impact and express the self. The Wailing Wall (i.e., Western Wall), the major symbol of the Jewish people, is steeped in history, being the surviving remnant of Solomon's second temple (Figures 3 and 4). Worshippers travel there to pray and reaffirm their faith. This sacred object and place is a reminder of Jewish historic and cultural roots, encourages solidarity among Jews worldwide, and reaffirms the religious self.

Similarly, over one million Christians pilgrimage each year to Mary's House (Figures 5 and 6), the place discovered in 1881 near the ancient city of Ephesus, Turkey, where the Virgin Mary is thought to have lived her last years (Carroll 2000). Here again, we see a designed form that is small in size and simple in its physical aspects, but one to which visitors assign complex and very personal meanings.

Architecture has the capacity to connect to the self, and our interpretation of places and things often reflect who we are or what we would like to project about ourselves to others. In similar fashion, the fields of ecological symbolic interactionism and eco-psychology are revealing much the same "self-environment" principles, but with focus on the natural environment. For example, Thoreau's 1854 Walden, or Life in the Woods, causes some to view the Walden area as a "place celebrated," a sublime wilderness where one can reflect on the self and meaning of life. Others see a "place on display," a glorious place used to translate theories about nature and science into lessons about "holism and organicism." Still others view it from a perspective of "place denied," or as a place standing in contrast to ordinary places that are standardized, cloned, and to be ignored (Gieryn 2002a:130). As surely revealed in all these meanings, Walden Pond is interpreted by many as a special place to come to know and/or express the self.

\section{ARCHITECTURE AS A SYMBOLIC ENVIRONMENT}

In referring to built forms, Lawrence and Low (1990:466) state: "As symbolic, sites condense powerful meaning and values; they comprise key elements in a system of communication used to articulate social relations." Symbolic interactionists maintain that human beings exist in a symbolic environment of social objects and shared language, and consistently emphasize that architecture does not have "intrinsic meaning"; that it is, in fact, people who give it meaning (Blumer 1969:68). Although some social scientists have seemingly assumed that designed forms have direct consequences for behavior, and might conceivably cite as evidence the ongoing and predictable economic successes of such standardized physical designs as McDonald's and Denny's restaurants, most symbolic interactionists would find this so-called "architectural determinism" simplistic and problematic. Instead, they would see architecture as suggesting possibilities, channeling communication, and providing impressions of acceptable activities, networks, norms and values (Ankerl 1981:36). Interactionists would more likely see the impact of designed forms as potentially influencing-but not as determining-thought and action (Duffy and Hutton 1998:8-21; Heismath 1977; Steele 1981). 


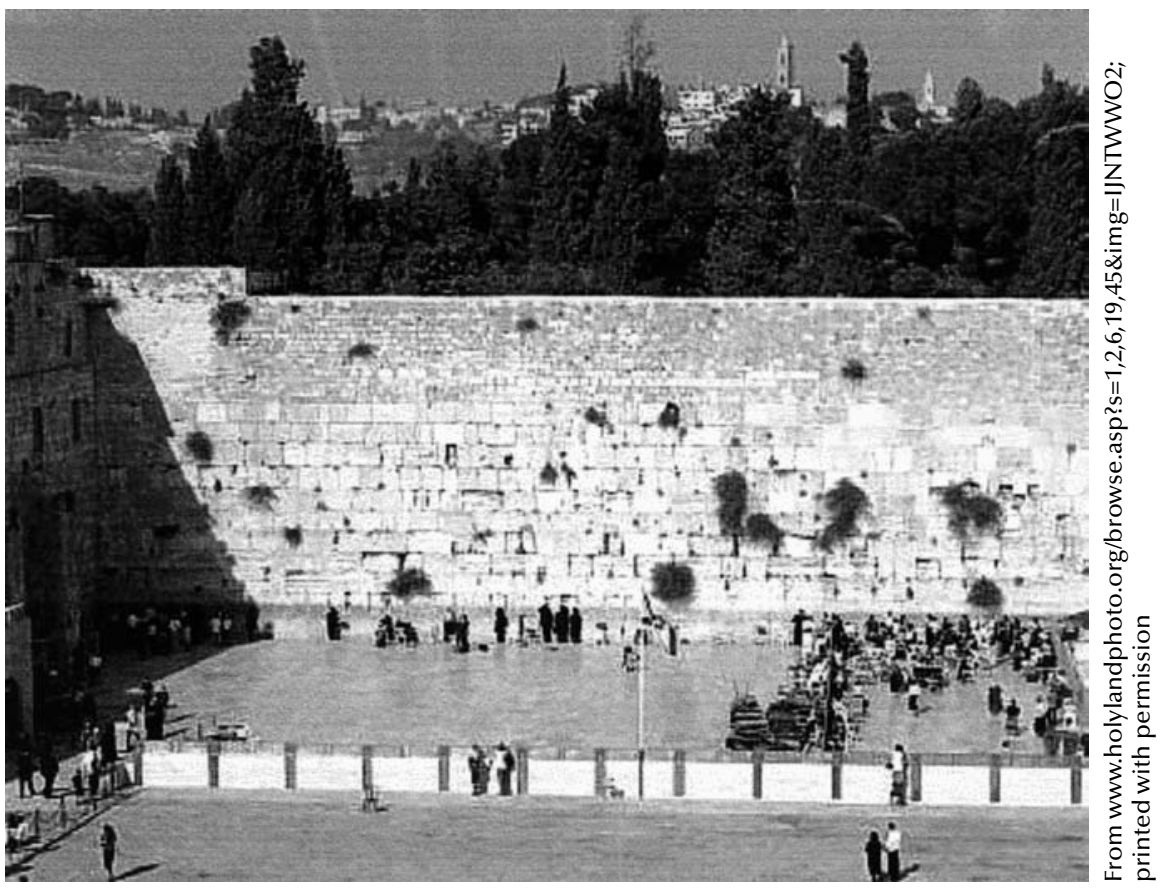

FIGURE 3. Western Wall, Jerusalem, Prayer Area

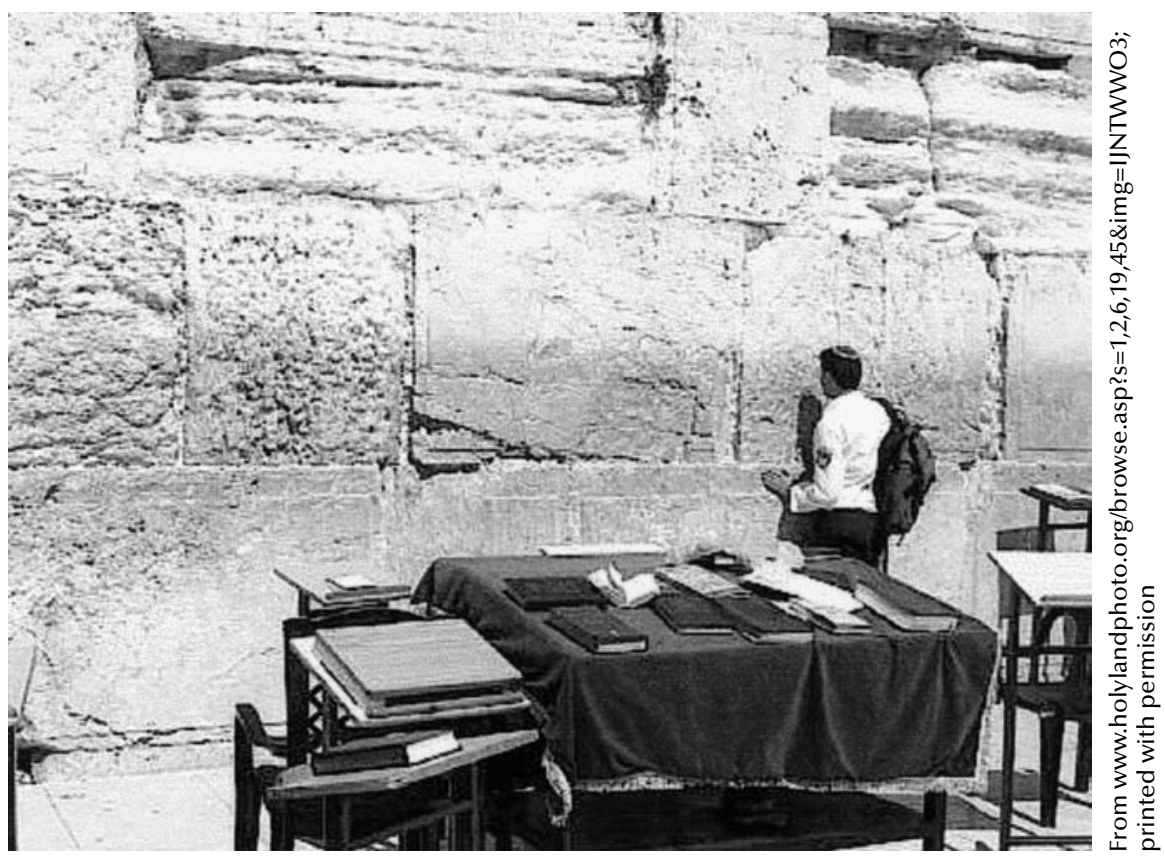

FIGURE 4. Worshipper at Western Wall, Prayer Area, Jerusalem 


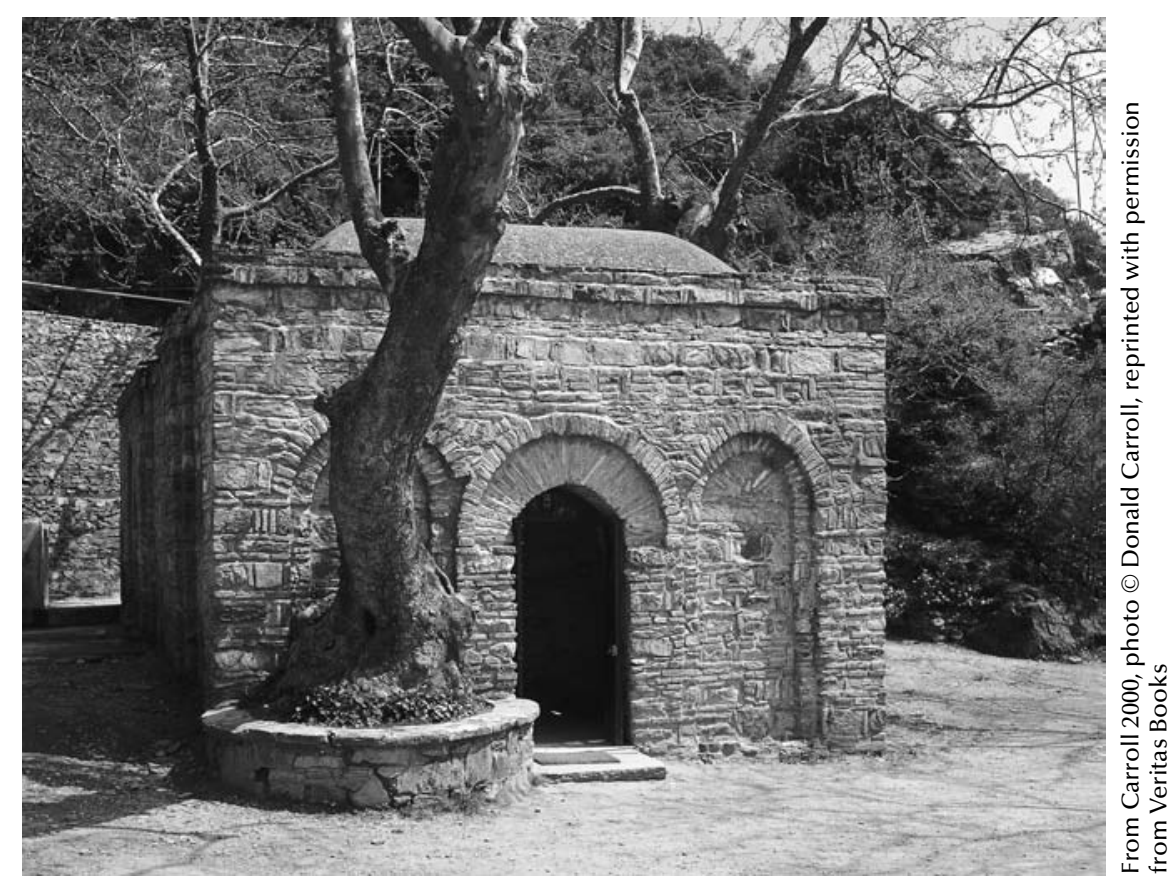

FIGURE 5. Mary's House, Restored Exterior

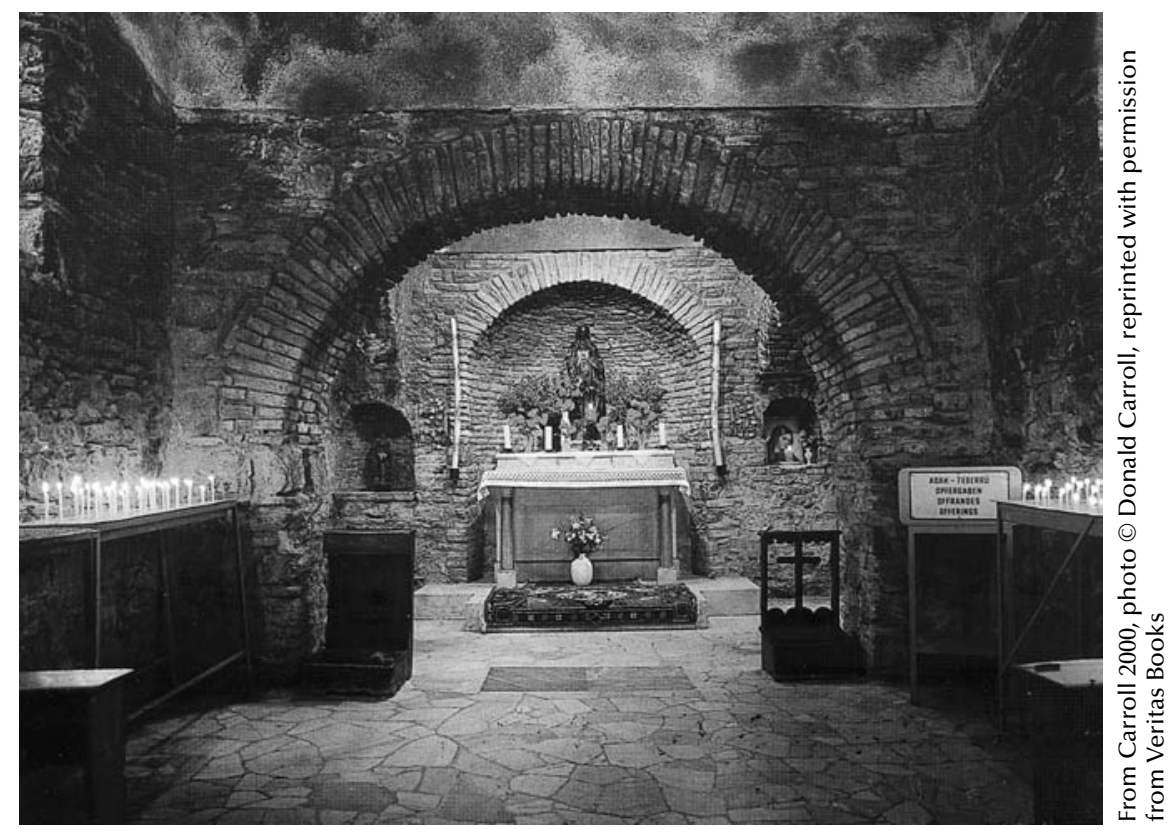

FIGURE 6. Mary's House, Restored Interior 
Symbolic interactionists give importance to the on-going and reciprocal processes of structure and agency. Representing the structural side of what is called the "structure versus agency" debate, Pierre Bourdieu (1977) argues that inhabitants take the symbolic classifications of their dwellings for granted, whereas Anthony Giddens (1990) emphasizes the importance of agency as he discusses how inhabitants negotiate and interpret the meanings of their buildings. The latter stance is emphasized in classic statements by Cooley (1902), Mead ([1932] 2002, 1934), Blumer (1969), and Goffman (1951), who maintain that humans are in an ongoing process of shaping and reshaping the meanings of self, others, and objects. In a recent statement about structure and agency in architecture, Gieryn (2002b:41) contends that buildings have a double reality- "as structures they structure agency but never beyond the potential restructuring by human agents." Gieryn uses the term "interpretative flexibility" to express that although architectural artifacts indeed influence conduct, these artifacts also mean different things to different people, and individuals can, of course, always change their definitions of these artifacts (p. 44). Illustrations of this flexibility might be seen when office workers abandon the use of a predesigned workroom because of its physical distance from their regular offices, or initially define a building as large and representative of grandeur but later see it as nothing more than wasteful and pretentious.

Architectural semiotics focuses on how the formal characteristics of designed forms contain signs or codes, and how these signs or codes constitute a kind of language (Eco 1972). This specialization has given some attention to the cultural meanings underlying these signs or codes. For example, Gottdeiner and Hutchison (2000) refer to spatial semiotics, a subfield within architectural semiotics, as the study of how designed spaces of urban places reflect culture. In need of further examination are the complex and varied cultural meanings that are initially assigned designed forms and, once established, how these meanings are then interpreted, later reinterpreted, and perhaps even changed by users. It is in these areas of investigation that symbolic interaction theory and its methodologies could greatly contribute to our understanding of person-architecture connections. Winston Churchill reflected a double reality about architecture when, in a 1924 architectural awards address, he made the simple observation, "We shape our buildings and afterward our buildings shape us." We could appropriately extend the quote to read "and then after use, we may choose to shape the buildings still again and perhaps even again."

Among the early symbolic interactionists who contributed to the understanding of the meanings attached to designed forms was Erving Goffman. Although he focused most of his attention on self presentation, in doing so he also noted the use of, and meanings assigned to, designed physical objects and places (Riggins 1990). Goffman (1951) refers to those buildings, objects, and places that express a prestigious style of life as "status symbols"; they represent the high social standing of a group and they can be used to exclude others. Gated and guarded communities, large homes, large wood desks in executive suites, formal gardens, unusual lighting, and expensive fabrics and metallic finishes, as well as other architectural artifacts, 
are often viewed as status symbols. "Indigenous and exotic objects" are described by Goffman as decorative objects that evoke other places and times. As an architectural expression, displaying antique Japanese woodblock prints, Chinese antique furniture, early Colonial American art, or antique Persian rugs would be examples. Goffman refers to "collective objects" as those that represent community ties. His discussion parallels that of Durkheim ([1915] 1976), who examines how designed objects and spaces are integral to social life, are attributed meaning, and serve as "collective representations" of a community. The Potsdamer Platz of Berlin, the Eiffel Tower of Paris, and the mosque of al-Haram in Mecca are examples of collective representations for different groups. "Stigma objects" are associated with spoiled identities and deviant activities (Goffman 1963). Users may associate stigma with certain types of architecture, such as homeless shelters, slum housing, old style prisons, insane asylums, or Stalinist architecture, because these designed forms are associated with people and activities defined by some audiences as soiled or deviant. Goffman further discusses how architecture can contain "disidentifying objects." Although these objects are intended to evoke certain meanings in audiences, they are in fact inauthentic, misrepresentative, and disingenuous of the people they represent. Homes and executive offices filled with reproductions of art and antiques, or books of high literary merit but which have never been read, are used to symbolize respectability and status, but in fact are disidentifying of the occupants.

More recently, Mary Jo Hatch (1997) uses symbolic interaction theory as a perspective to help us understand organizations, including the architecture used by organizations to influence their users. She maintains that the theory informs us that the designed physical environment contains cues that communicate messages to people - that remind them of the expected roles of themselves and others. She states: "Those who adopt the symbolic view see the physical structure of an organization as shaping and maintaining a system of meaning that helps organizational members to define who they are and what they are doing" (p. 251). For example, the design and use of office cubicles suggests standardization of routine work among those assigned this type of space; and executive offices on the top floors of a multi-story business building suggest both a steep hierarchy of administrative authority and the location where important decisions are likely made.

Architects, too, have focused intensely on the symbolic meanings attached to their designs. Of special interest in this regard is the "social design" movement that began in the 1960s, when architects and social scientists coordinated their efforts in applied design. In this conflicted time, with public focus on issues of race and gender inequality, civil rights, and environmental damage, the movement sought to correct misalignments between people and their built environments. Defining social design as the process of creating physical environments that meet both the physical and the social needs of the occupants, Robert Sommer $(1969,1974,1983)$, an environmental psychologist, demonstrates in practice that architecture has symbolic significance and can be created to improve the lives of users. For example, in designing a project for hotel workers located in Fiji, Sommer's ethnographic research re- 
vealed that a large traditional village consisting of housing, shops, and services would be inappropriate. Workers came from a variety of islands with different cultural views, and most were unfamiliar with a subsistence economy. The end result was that small villages were built that were better suited to meet the cultural differences and prior experiences of workers (Sommer 1983:107-8). Similarly, John Zeisel $(1975,1977,1984)$ incorporates familar cultural symbols in his architectural designs as a means to assist with various human problems, such as easing the transition for, and encouraging a new sense of place identity among, seniors who have recently moved to a retirement home. As another iteration of the social design movement, architect Fritz Steele $(1973,1981,1983)$ seeks to create better workplace and organizational designs. He argues that specific designs can improve social interaction, foster symbolic identification, and enhance personal pleasure and growth. Another representative of social design, architect Robert Gutman (1985, 1988), goes beyond design to solve human problems and focuses on how architects should actively intervene to influence politics in regard to societal problems, such as availability of low-cost housing.

Architecture professor Howard Davis in The Culture of Building (1999) summarizes contemporary examples of architects worldwide who practice some form of social design. They hold in common the goal of creating buildings and places that are highly symbolic, culturally reinforcing, people-centered, and problem-solving. Thus, we see that the social design movement is consistent with social science perspectives, including many of the basic tenets of symbolic interactionist theory. Social design architects, rather than focusing solely on the artistic merits of architectural design and project completion., seek to understand how and why people attach meanings to designed physical forms and how these forms can impact lives in positive ways,

Design professionals create designed forms to convey specific meanings, such as fun and entertainment (e.g., Disney World in Orlando and the Mandalay Bay Hotel in Las Vegas), neighborliness and community (e.g., new urbanist communities like Seaside Florida), worship of the supernatural (e.g., Chartres Cathedral in France), and rest and retirement (e.g., Sun City, Arizona). Three of the most pervasive architectural goals of design professionals are (1) to preserve an existing thought system or way of life; (2) to control and, in extreme cases, punish people; and (3) to promote social change.

\section{Preserving Existing Thought and Conduct}

Architectural forms can be designed and used to reflect and reinforce our existing meanings for the world. For example, a home can be intentionally designed to reflect and preserve one's culture of origin. Amor (2004) conducted a qualitative study of home designs in three Arab Muslim immigrant communities in Dearborn, Michigan, Chicago, Illinois, and Modesto, California, and discovered that Arabian majlees (sitting rooms), al-madkhal (doorsteps), atajmeel (decorations), and sutra (privacy) were common design elements that occupants created as symbolic reminders of a cultural heritage and personal identity they hoped to preserve. 
Reise (1950) has shown that architecture can be used to reflect and reinforce a profession's ideology. Prior to 1800, the mentally ill were thought to be possessed by demons, and were often placed in designed forms, most typically dungeons (with criminals and other "undesirables"), where they were subjected to "treatments" including beating, bloodletting, and purging. At the close of the eighteenth century, French physician Philippe Pinel dramatically altered the ideology of mental health professionals by his humane treatment of patients. Believing that these illnesses were in large part due to social and psychological stresses, he promoted the segregation of the mentally ill from other deviants, the removal of chains, and an end to torture techniques. Instead, he proposed using counseling and activity-based treatments, and more importantly for our discussion, the building of asylums.

Prior to the 1950s, psychiatric hospitals, or socalled mental asylums, were often constructed according to Kirkbride design: a single building, sometimes Gothic in style, located in isolated rural places where inmates were segregated from the mainstream community. All types of patients were warehoused in the same institution, and all social, therapeutic, and other facilities were on site. The architectural design, in fact, reflected the dominant belief of professionals at that time that the mentally ill should be treated humanely, and also communicated that professionals could distinguish physical diseases from mental illness, sanity from madness, and the normal from the abnormal (see Figures 7 and 8).

The construction of these asylums did not stop until the late 1950s, when another shift in thinking occurred among mental health professionals-as well as social workers, nurses, and occupational therapists - that supported the integration of the mentally ill into the larger community. An entirely new variety of architectural forms developed that bridged hospital with community, including hospital wards, day centers, day hospitals, and community mental health centers (Prior 1993). Architecture reflects, preserves, and promotes ideology; in this case, of how mental health professionals define the nature of illness and appropriate treatment.

Designed forms can embody, and therefore promote, the most important tenets of a culture (Forty 1986). Rob Shields (1992) has thoughtfully examined shopping malls in contemporary America, which are not only designed consumption sites for the masses, but also sites that reinforce some of America's most idealized values. They are places designed to appear democratic because of their supposed accessibility to all visitors, although in reality some groups that are seen as interfering with consumption might be excluded (e.g., the homeless). Malls present themselves as places of plenty. They combine leisure, sports, novelty, and excitement, all of which are highly valued in contemporary American culture. And they utilize highly valued existing architectures such as train stations, theaters, museums, and historically important buildings in an attempt to a create an imagined communal past, or dream quality, about the shopping experience. Malls often attempt to symbolize and celebrate America's consumer culture and simultaneously provide consumers with feelings of the good life that we have all been promised but that, in fact, only some achieve.

Shields' analysis would seem to fit perfectly the design of the Mall of America in 


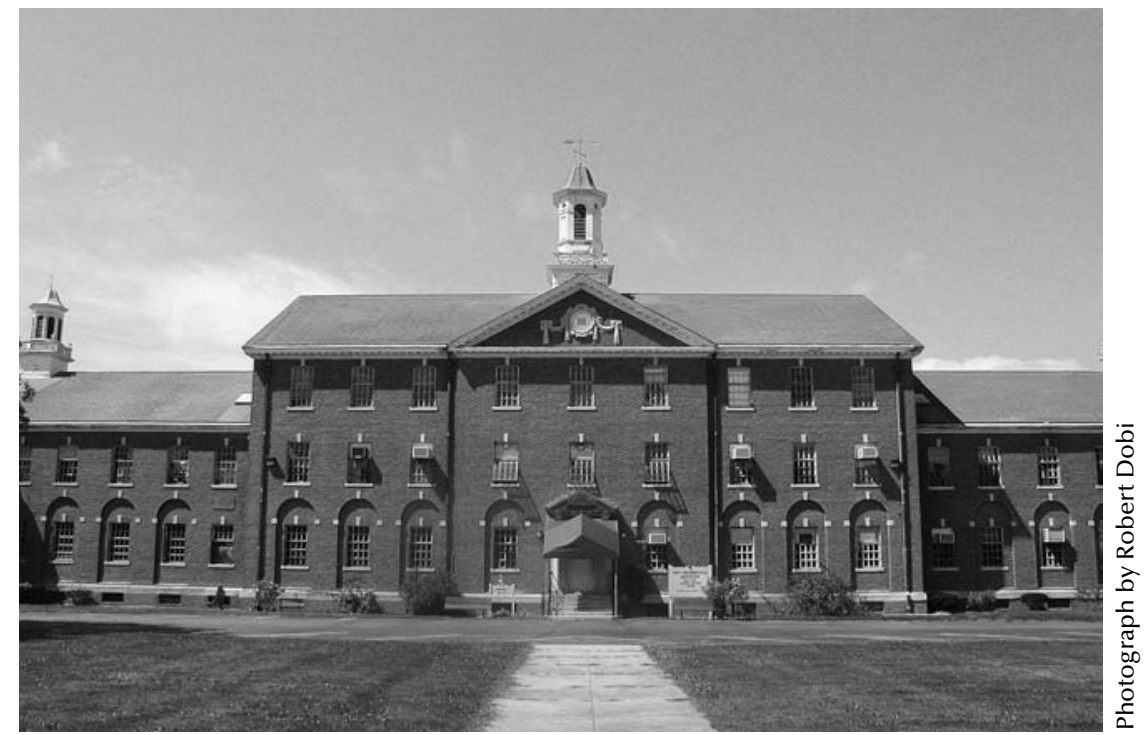

FIGURE 7. Exterior View of the Main Building of the Now-Abandoned Fairfield Hills State Hospital, Newton, Connecticut

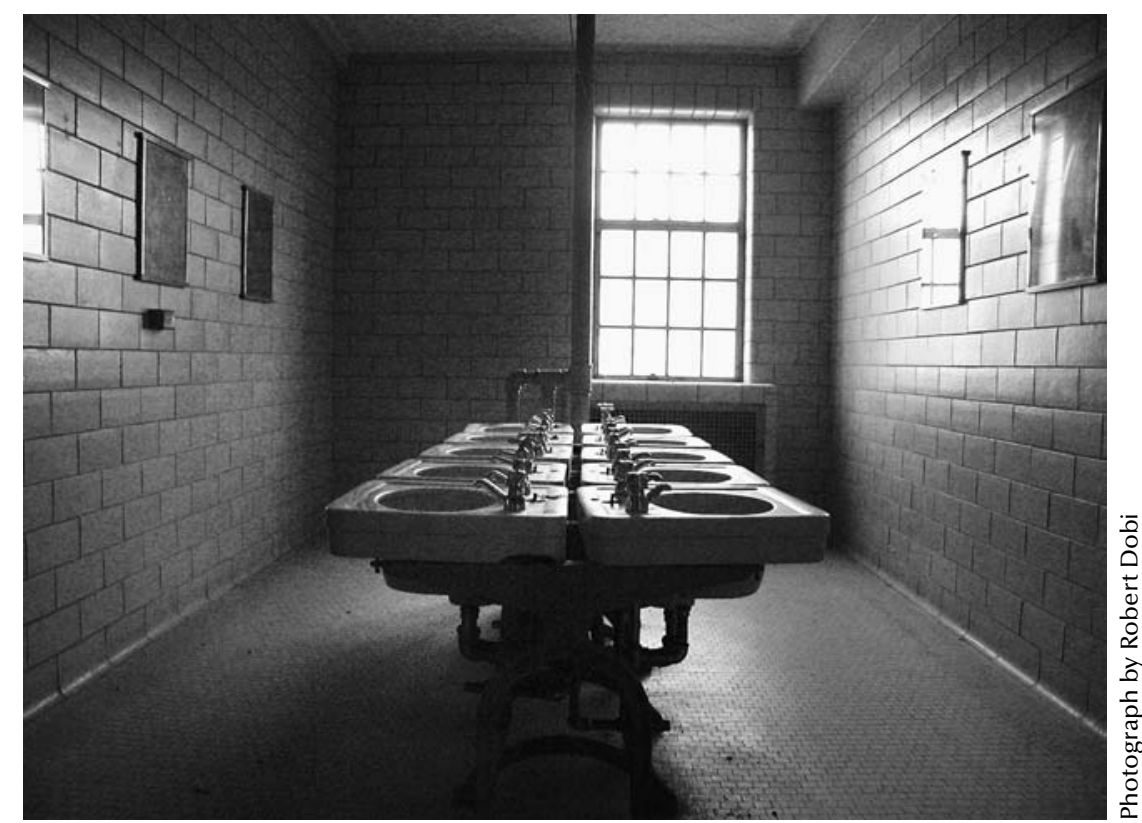

FIGURE 8. The Washroom at Fairfield Hills State Hospital 


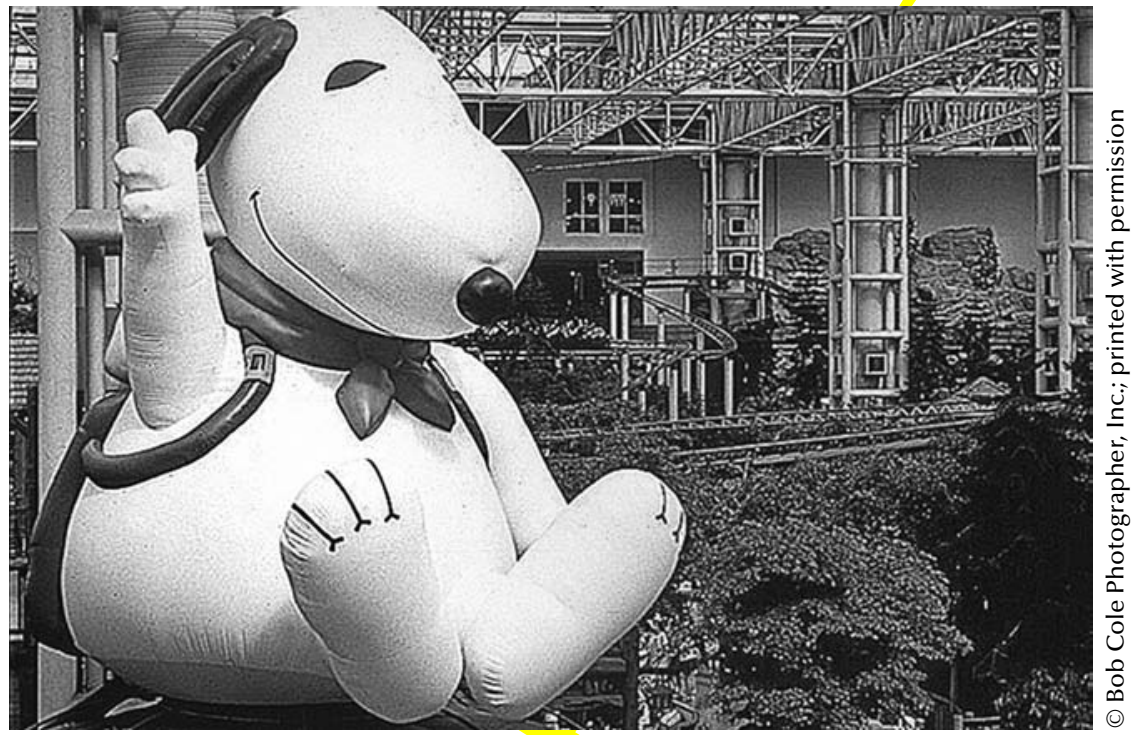

FIGURE 9. Camp Snoopy Amusement Park at the Mall of America, Bloomington, Indiana

Bloomington, Minnesota. The shopping center bills itself as the largest fully enclosed retail and family entertainment complex in the United States. It contains some 500 stores, a 1.2 million gallon aquarium called Waterworld where you can dive while bystanders watch, fourteen movie screens, the Camp Lego Imagination Center, Golf Mountain, the Award Circle for the NASCAR Silicon Motor Speedway, 30,000 plants, 400 trees, wedding facilities, the Pepsi Ripsaw roller coaster, and Camp Snoopy Amusement Park (Figure 9).

\section{Conveying Control}

Architecture may represent differential status and one group's control over another. Daphne Spain points out that designed forms, especially spatial arrangements, can be used to perpetuate male dominance over females. For example, she argues that women in the U.S. workplace continue to occupy a disproportionate number of lower status jobs and are often spacially segregated from males in designed places that lack privacy, are under constant surveillance, and where women would be less likely to receive important information that could result in higher pay and promotions (Spain 1992:227). Marginalized groups of all types-racial and ethnic minorities, the disabled, and the poor-have historically been denied access to particular public places and facilities resulting in segregated schooling, diners, public restrooms, swimming pools, and transportation. In such cases, architecture can be seen as a means of control by those in power (Rendell, Penner, and Borden 2000). 
Architectural design can extend messages of control to convey meanings of punishment and death. The Panopticon Penitentiary, designed in 1787 by Jeremy Bentham and subsequently widely implemented (e.g., the now-abandoned Stateville Prison in Joliet, Illinois), was devised so that large numbers of prisoners could be observed at all times. The Panopticon is a cylindrical building of multiple stories consisting of open-sided cells with one-way directional light, a feature that allows for easy guard observation while limiting the ability of prisoners to see those in the central tower observing them (Figure 10). Originally designed as an alternative to the then-common practice of solitary confinement of prisoners and as an improved

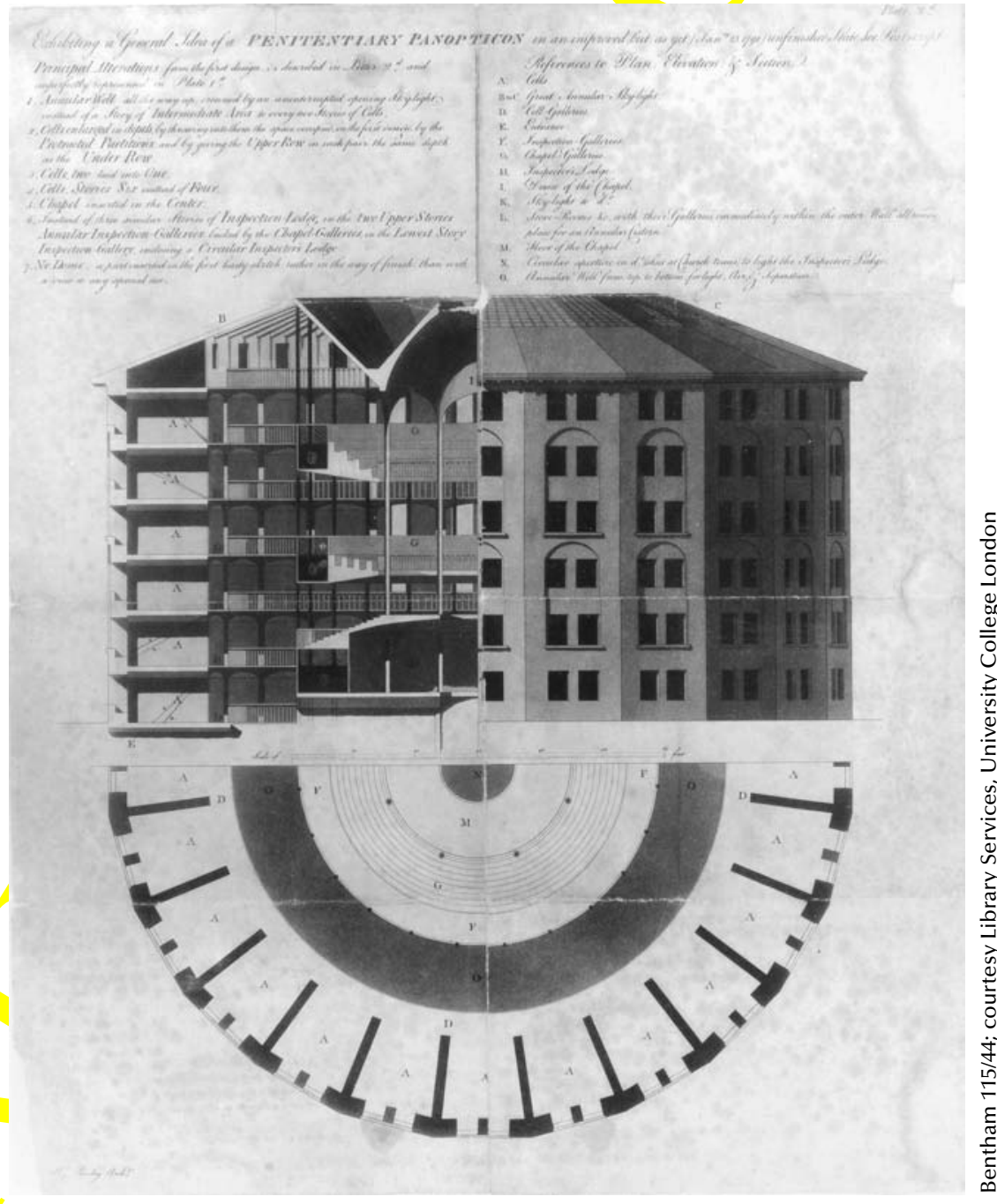

FIGURE 10. Bentham's Plan and Text for the Panopticon Penitentiary, 1787 
means to achieve rational order and efficiency, the design eventually came to be defined as excessive in terms of control, or a pantheon of punishment (Levin, Frohn, and Weibel 2002:114-19). Foucault (1979), among others, used the Panopticon as a symbol to describe the oppressive surveillance practices in all of our lives.

The architectural designs of World War II prisoner-of-war camps startlingly conveyed meanings of torture and death. The camps of Japan (e.g., Akenobe \#6, Fukuoka \#1, and Osaka \#3), Germany (e.g., Dulag Luft), Rumania (e.g., the Stalags), and Austria (e.g., Mauthausen) were designed as instruments conveying power, fear, torture, executions, and dehumanization. The Nazi camp of Dachau, located in southern Poland, where a minimum of 2.5 million prisoners died between 1939 and 1945, is a prime example of such architecture, with its carefully designed granite fortress, watch towers, nearby railway to transport prisoners, four gas chambers designed to appear as showers, four crematoria, incineration chimneys, cell blocks, isolation cells, labor camps, kennels for watch dogs, and prisoner courtyards. It was a designed object and place for the ultimate form of control-the extermination of Jews, Soviet prisoners of war, Gypsies, homosexuals, and political dissidents.

\section{Promoting Change}

Architecture can be used to promote social change. Benjamin Latrobe, often referred to as America's first architect, was commissioned by President Thomas Jefferson to design the White House and the U.S. Capitol building (Figure 11). His socalled "plain design" for architecture, which merged the ideology of ancient Greece with industrialized nineteenth-century America, clearly reflected a new country and a changed vision of life. At that time, the tradition, detail, and grandeur of Italian Renaissance and Italian designs dominated architecture. In contrast, Latrobe's buildings were to represent simplicity, geometric power, and rationalism, and his style appealed to a nation of youth, enthusiasm, and search for originality.

Another who used architecture to illustrate a new era was Walter Gropius, architect and founder of the famous German Bauhaus School in 1919. He eventually came to America and designed buildings that supported the mass citizenry and rejected all that might symbolize bourgeois thinking. His buildings were made of socalled "honest" materials, such as concrete, steel, wood, and glass, and lacked bright colors and ornate decorations, such as spires, corbels, and Spanish roofs, which he saw as pointless, excessive, and unrelated to the daily human activities of workers and families within the structures. They contained low ceilings and narrow hallways, because spaciousness was seen as bourgeois grandiosity. His buildings were designed to symbolize the need for change in a functional, modernist world, and his efforts led to what is called the "modernist architecture" of most buildings in today's largest American largest cities. (Wolfe 1981).

An example of using architecture to promote change in an community can be seen in the highly successful attempt to reinvent Santa Fe, New Mexico, as a major tourist destination. Beginning in 1912, community leaders, most of whom were 


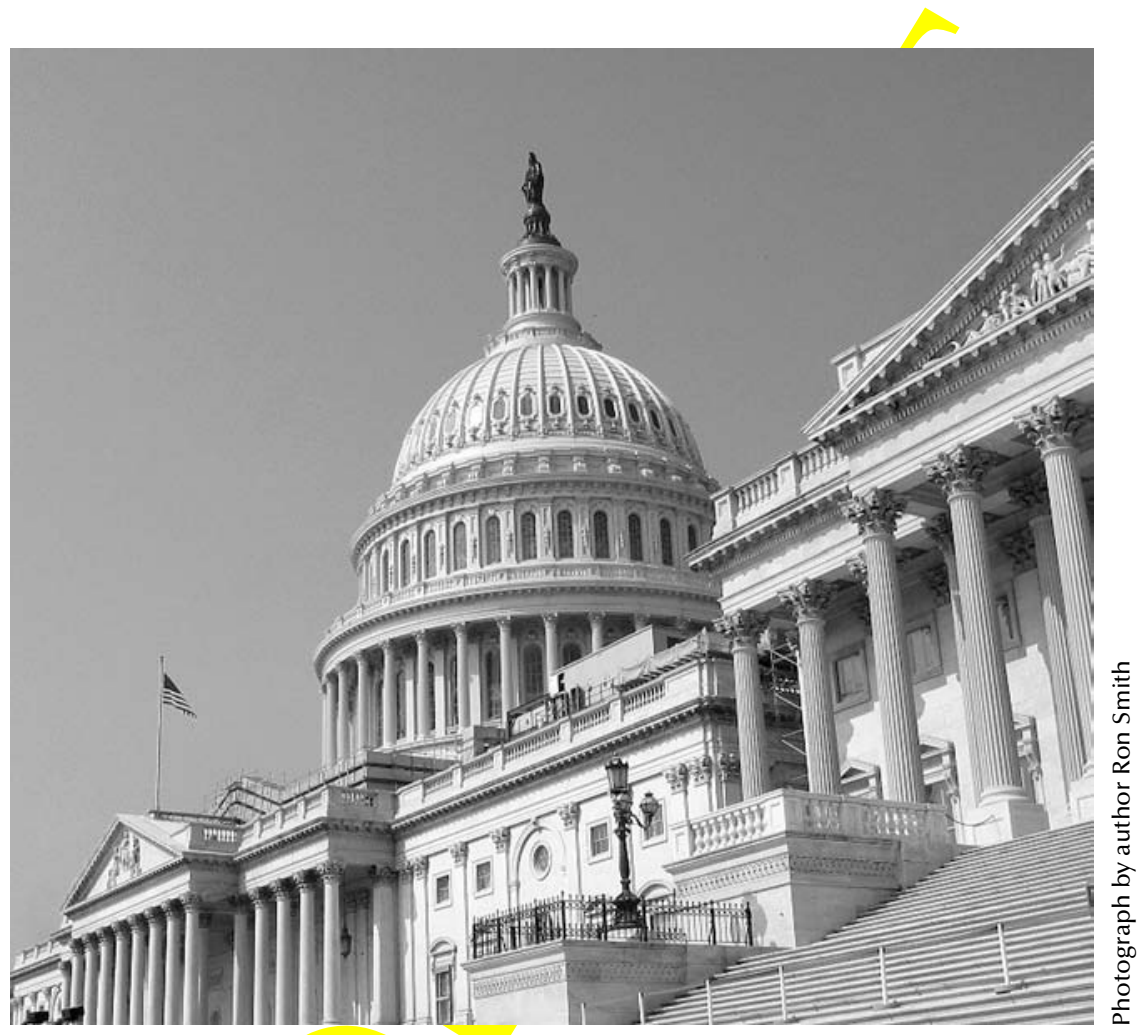

FIGURE 11. U.S. Capitol

Anglo-American newcomers, sought to rebuild the town in the "Pueblo style" to create a plausible fiction about the cultural history of the region. The reinvented Pueblo architectural style was, in fact, fueled by tourists and their romanticized vision of the Southwest, and embraced by local businesses that sought a corporate image to enhance the community's economic vitality (Wilson 1997). Figure 12 shows the early version of the style, implemented in the Institute of American Indian Arts Museum; Figure 13 shows a more recent and modernist version of the Pueblo, used for the Inn of the Anasazi. The Pueblo style of design (now called Santa Fe style) continues to have widespread community impact, communicating a version of the region's history and assisting in the marketing of tourism and new businesses.

Architects also use design to stimulate a renewed way of thinking, or encourage social change, with primarily environmental preservation (rather than profit) motives in mind. Johnson (2004) reports on several studio design projects that focus on the preservation of the Sonoran Desert landscape. These include the Urban Edge site in Tucson, Arizona, where visitors are confronted with surreal artifacts that encourage questions about contemporary land practices as compared to those used by the Hohokam, the early settlers in the area who revered the land. The Faint Fragrance of Space site in Tucson features a narrative that invites the user to smell 


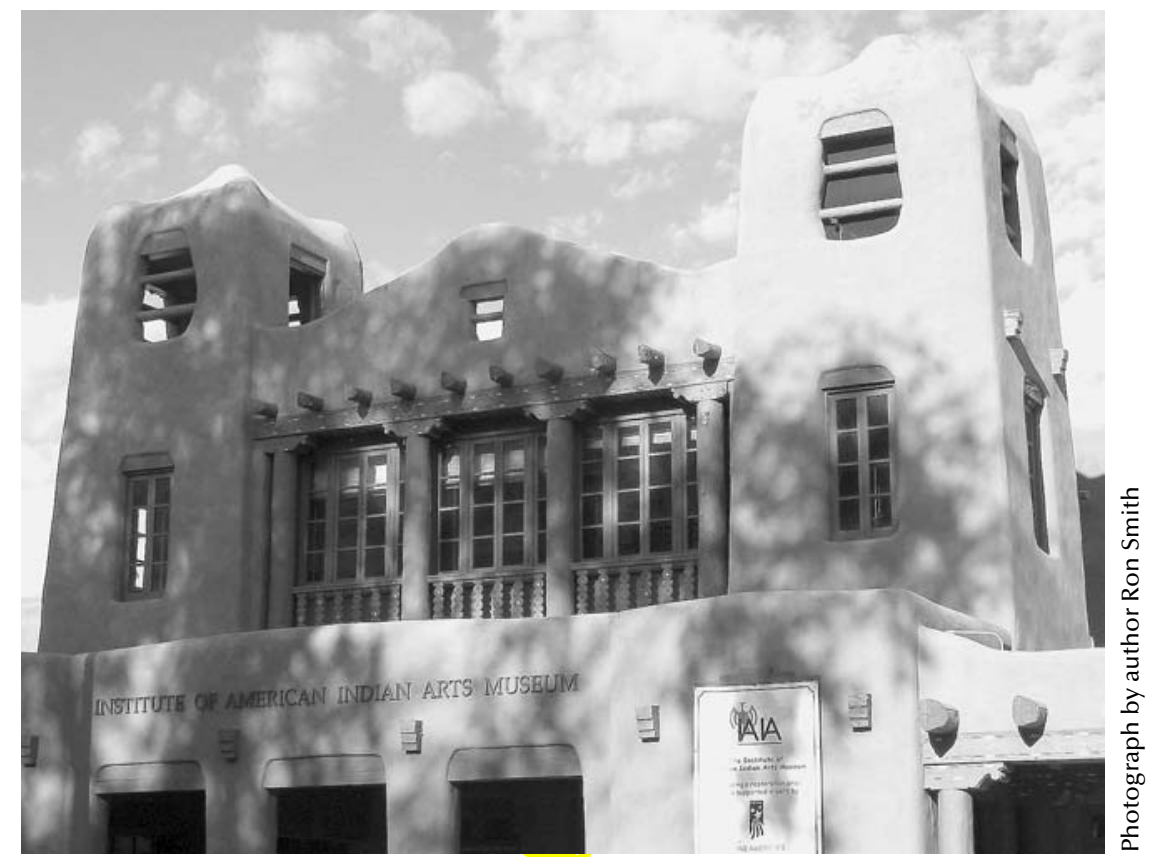

FIGURE 12. Early Santa Fe architecture. Institute of American Indian Arts Museum, Santa Fe, New Mexico

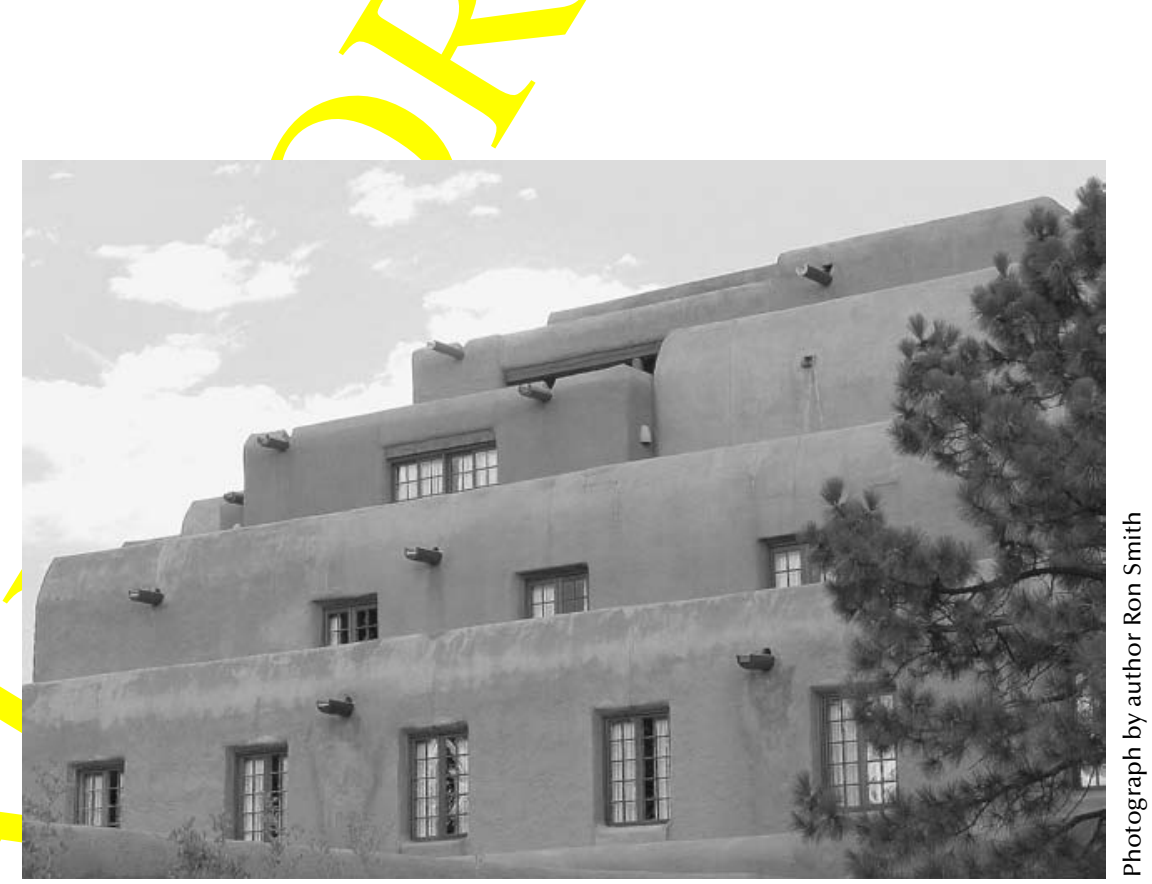

FIGURE 13. Modernist Santa Fe Architecture. Inn of the Anasazi, Santa Fe, New Mexico 
the fragrance of creosote plants after rain so as to elicit memories of the beauty of the desert and encourage its protection as a natural resource. Finally, the City Limits/ Desert Limits site includes a trail replicating the Tucson city limits and uses materials made of recycled tires and glass as a means to educate guests about urban sprawl and a sustainable environment.

Finally, it is important to recall that despite the intentions of architects, the meanings of their designed forms are subject to human interpretations. For example, some have suggested that postmodern architecture is a symbol of change, as was its intended purpose, while others maintain that it is no different than modernist architecture except in its use of decorativc facades and therefore sumbolizes no change (Habermas 1989, Jameson 1991, Harvey 1989). Postmodern architecture was originally conceived in the early 1970s as a condemnation of modernist architecture's minimalist, anonymous, monotonous, cold, and boring style. Accordingly,

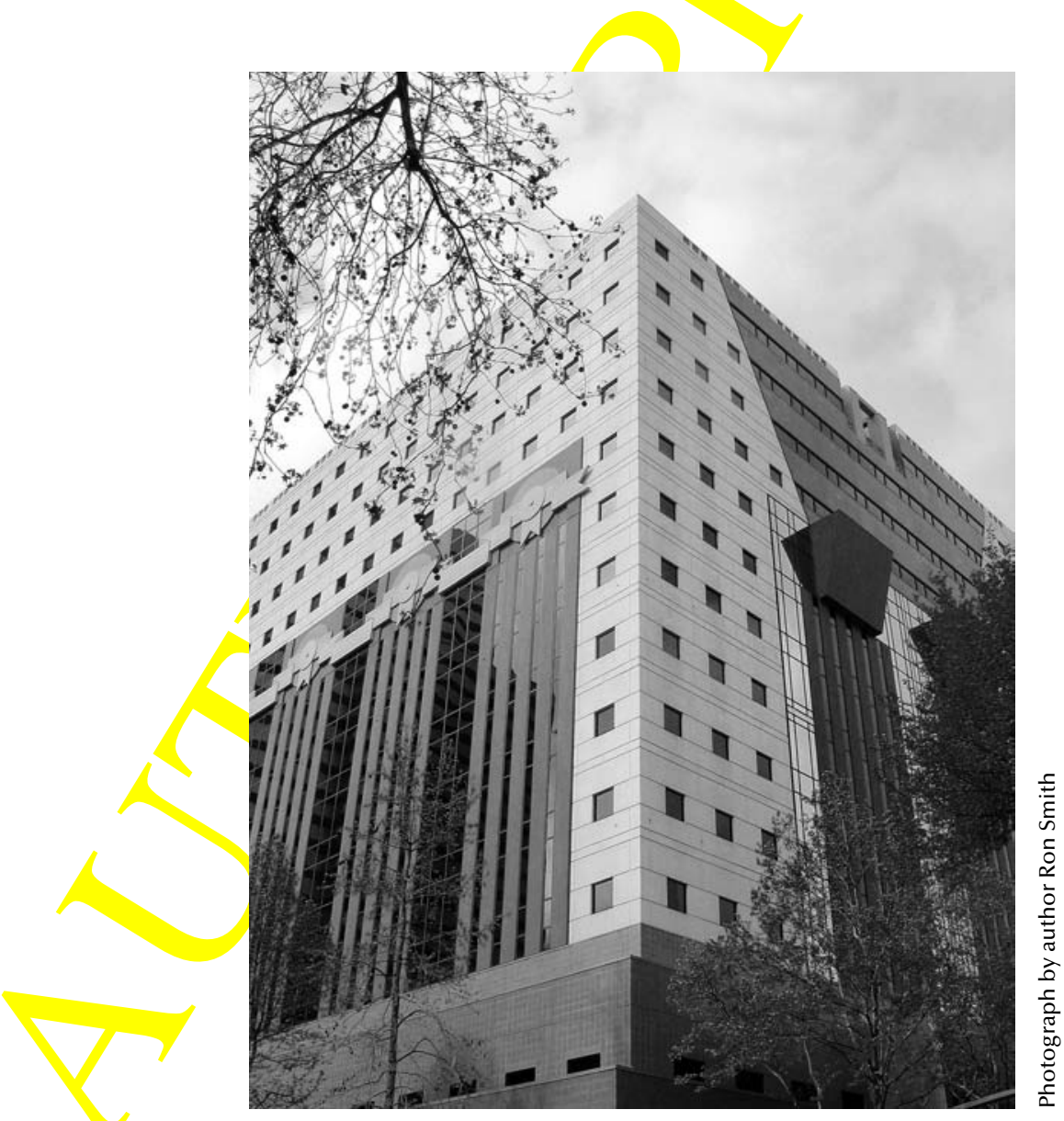

FIGURE 14. Portland, Oregon, Municipal Building, Postmodern Design by Michael Graves 
postmodernist architecture was often "doubly coded," symbolically part modern and part traditional: complex and contradictory in meaning, and sometimes sleek, asymmetrical, humorous, and ambiguous in form (Baudrillard 1994; Habermas 1989; Jencks 1977). The metaphoric and symbolic characteristics of postmodern architecture are exemplified in the Portland, Oregon, municipal building (Figure 14). Designed by Michael Graves, the building combines the internal design of an efficient and responsive machine with a colorful and decorated external image that piques interest and welcomes the public. The external design resembles a decorated package with its vivid colors of browns, blues, and rusty reds, stylized garlands, and an image of a woman above the main entrance.

\section{ARCHITECTURE AND AGENCY}

Symbolic interaction theory suggests that physical objects and places do not just provide a setting or backdrop for conduct, but that humans have the capacity to assign agency to these designed forms. Werlen (1993) argues that the designed physical environment has a detectable and seemingly independent effect on social life. One could reasonably ask how it can be that a building, designed interior, or landscaped environment - all of which are nonhuman objects and places-have agency that could result in user response? Interactionists explain that people interact with physical environment, designed or natural, in a manner similar to how they interact with people; individuals detect and internalize the roles of these physical objects and places with presumed mutuality (Cohen 1989). People think about architectural artifacts; they examine and interpret them; and they interact with them. As a result, we assign agency to the designed form as we forge our conduct. As Mead states, "Physical things are objects implicated in the social act whose roles we can take but which cannot in turn take our roles"(Mead 1934:xxii).

In an excerpt taken from How We Think by John Dewey, Joseph Cohen (1989: 197-98) illustrates interaction between humans and designed physical environments, and the power of designed forms to influence human thinking and conduct. In the story, a student detects a horizontal pole on the upper deck of a ferry boat. Having no idea of its purpose, the student tries to imagine all the possible purposes of the pole, posits several hypotheses, reflects on the visual evidence to eliminate certain explanations, and eventually concludes that its purpose is to show the pilot the direction in which the boat is pointing. This object becomes obviously important for navigation in dark or foggy situations. On the basis of this example, Cohen argues that as we view physical objects, we conjure up all reasonable hypotheses that would explain its meaning or purpose, and then we internally test the relative merits of our hypotheses. In this sense we seek out information from the physical environment-clues-which then allow us to draw conclusions and respond.

In a classic illustration, Mead (1934) recounts the story of an engineer constructing a bridge. The engineer describes the bridge as if it were a person. The engineer realizes that there are construction stresses and strains that must be met, thus tak- 
ing the attitude of the other, which in this case includes both the physical object of the bridge and its location within a natural environment, and then adjusting his conduct in order to complete the bridge. The point of Mead's story is that humans take the role of physical objects and places, that we interact and form a social relationship with this environment (albeit one-way), and that physical objects and places have profound impact on our formed responses. Symbolic interactionists are not alone in their views about designed forms. The field of material culture holds that the physical environment is "socially alive" and that physical objects, mind, and behavior exist in co-dependency (Knappert 2002).

Not all designed physical objects and places are given agency; only some are given recognition and assigned an internal voice. Some designed physical environment is mundane and boring, and simply does not pique our curiosity and interest. Barthes (1986) and Broadbent (1980) suggest that the architecture to which we give relevance and thereby agency is that which we define as functionally important. It can include those objects and places we grant great symbolic meaning, or those that express the self. More recently, Owens (2004) suggests that interaction with physical objects is likely influenced by the urgency of one's goals and the primacy of the physical object to task completion. In regard to architecture, the places where we "live" and "work" are generally closely related to our personal goals and tasks we want to (or must) achieve, and will probably rank high as designed forms to which we give high priority and assign agency.

That some architecture has profound power over our thoughts, emotions, and behavior is not lost on architects; achieving these effects is the ultimate goal of many designers as they approach their projects. While we have established that the meanings and level of impact of designed forms can vary, some architecture has had profound impact on many users, including such as Rome's St. Peter's Basilica; the Mayan temple ruins of the Yucatan Peninsula of Mexico, Belize, and Guatemala; or Jordan's ancient city of Petra. Philosopher Jean Baudrillard and architect Jean Nouvel, in their book The Singular Objects of Architecture (2003), define these and other examples of cherished architecture as irreducible, irreplaceable, and transcendent artifacts that perfectly incorporate culture, time, and space for the beholder. They argue that such places and things create strong emotions for the individual, including a feeling that self and architecture are in total harmony or that the object or place helps to know the self as well as the world. Given our previous discussion, it would seem that these designed forms are assigned special powers of agency.

Both architectural critics and the public have come to define certain architectural objects and places as "great architecture." The professional and popular appeal of such architecture may be its special construction, design, or use, but central to these designations is that the designed forms have special meaning and are assigned agency. The object or place contains what Baudrillard and Nouvell (2003) call a "secret" for the user; it evokes memory and emotions and calls out for response. Among the multitude of designed forms often described in the professional literature as great architecture are Notre Dame Cathedral (Paris), the city of Paris 
itself, Angkor Wat (Cambodia), Alhambra Palace and Gardens (Spain), the Pantheon (Rome), Guggenheim Museum of Bilbão (Spain), Empire State and Chrysler buildings (New York), ancient city of Ephesus (Turkey), Forbidden City (Beijing), Vietnam Veteran's Memorial (Washington, DC), Jean-Marie Tjibaou Cultural Center (New Caledonia), Sydney Opera House (Australia), Guadalupe Cathedral (Mexico City), and Taj Mahal (India).

Also among the world's great architecture, Stonehenge, a Neolithic ruin that stands on the Salisbury Plain in Southern England, was built as early as 2950 b.c. Remarkable in its time, as well as today, it is $330 \mathrm{feet}$ in diameter and contains large stones-some as much as 6.5 feet wide and 13 feet tall-connected by stone lintels (Figure 15). Why has this designed object retained its appeal over the years? Some surely come to Stonehenge merely to experience the awe of megaliths of large size; marvel at the advanced engineering, construction, and design; and speculate as to how stones of such large size could have been transported from a distant place. Most wonder about the identity of the original builders and their ritual uses and meanings for the place. Others use the designed form to reflect on our human origins, or the very meaning of life. Whatever the reasons for its popularity, people have been dawn to this physical object and place and have assigned it some form of agency. It continues to spur them to think, reflect, feel, and act.

Another example of architecture with agency is the Dome of the Rock, an Islamic Mosque of octagonal shape with gold-covered dome, built in the heart of Jerusalem in the seventh century (Figure 16). Architecturally grand and beautiful, the three major monotheistic religions of the world look to this site to communicate history and traditions - and for worshipping God. The rock in the center of the

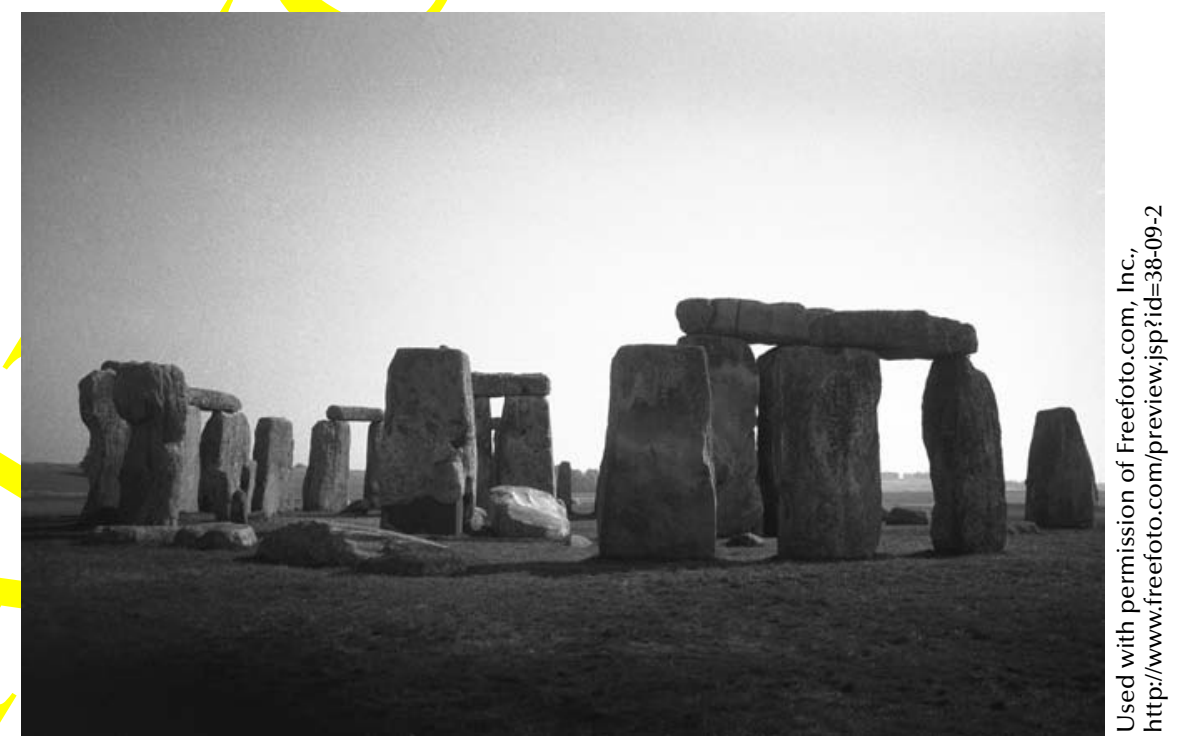

FIGURE 15. Stonehenge: A World Heritage Site 


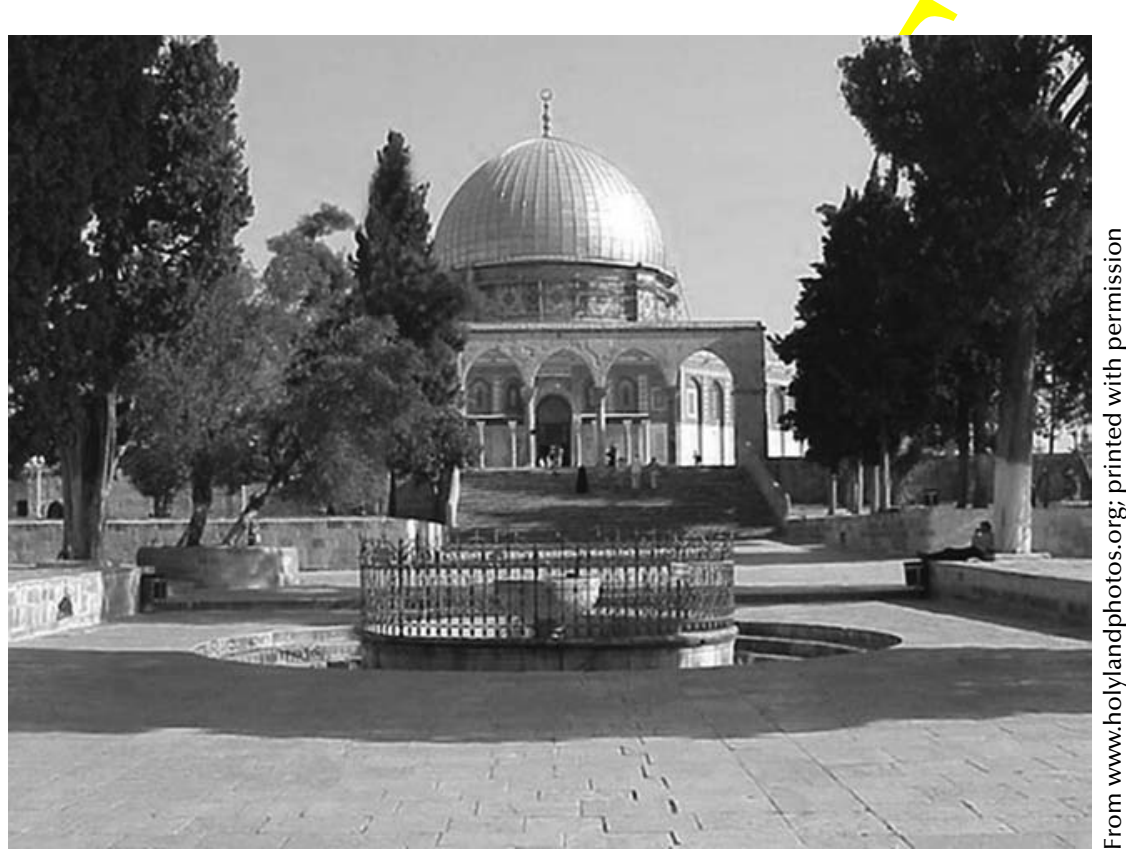

FIGURE 16. Dome of the Rock, Temple Mount Platform/Haram, Jerusalem

dome is thought by Muslims to be the place where Mohammad ascended to heaven to see God. Most Jews revere the holy site and believe it is where Jacob saw the ladder to heaven. Christians, too, believe the place to be associated with the life and ministries of Jesus Christ.

\section{SYMBOLIC INTERACTION THEORY AND THE DESIGN PRACTITIONER}

Symbolic interaction theory has something valuable to offer the design practitioner, both in concept and in design implementation, and those of us in this field have much to gain from the application of symbolic interaction theory, including the possibility of testing and advancing our own theoretical ideas, the opportunity to collaborate with another group of professionals on problems of common interest, and ultimately, a better chance of improving the places where people work, live, study, pray, and play. The following brief examples illustrate just a few applied linkages between the symbolic interactionist perspective and architecture.

\section{Designing Schools}

The school design principles associated with the German Weimar Republic and brought to the United States after World War II offer ideas for how to create pow- 
erful symbols for student learning, sound connections between space and expression of self, and connectivity between students and the larger community. The central principles are that furnishings should be moveable and scaled for students of different age and needs; classrooms should be designed for their special uses; classrooms and outdoor spaces should be paired, as learning occurs in both environments; schools should reinforce and be an extension of the community (e.g., its racial and ethnic composition and its major values and expectations); schools should be designed with proper circulation and use of natural light; and schools should be physically designed to prepare students both as "individuals" and "citizens" (Henderson 1997).

Several of these principles are consistent with the central tenets of symbolic interaction theory, including that an adult self is one that emerges by incorporating the attitudes of a complex set of others, or what is called the "generalized other." Once the outside world has been internalized, the individual then has the capacity to act in an organized and consistent way, in a manner consistent with changing situations, and in a way that reflects particular aspects of self. It would seem plausible that symbolic interactionists might want to assume the role of promoting school design principles such as those discussed above, while simultaneously critiquing "cookiecutter" school designs that all look alike, incorporate fixed seating and general-purpose classrooms, lack windows and skylights, and discourage teacher-parent interactions and community participation. The fact is, a great many of our schools are designed and built solely for containment of students, cost savings, and relative ease of construction, rather than to achieve goals of student learning and connection to the larger community.

School design extends beyond the classroom and onto the playground. Some landscape architects are attempting to enhance interaction among students, faculty, and community residents; to encourage common symbols; and to promote a greater sense of the generalized other through design and re-design of playgrounds. Brink and Yost (2004) report that, for over ten years, teams of school officials, community members, and landscape architecture students and faculty have been transforming playgrounds in some of the oldest of Denver's inner-city schools into learning environments. The designs combine elements of a public meeting place with an educational place that matches the developmental needs of children. The playgrounds are designed to improve student performance, encourage use by various groups, reflect the history and cultural makeup of the community, and promote community pride. To achieve these goals, the designers use inviting sitting spaces; hard surfaces for games and a variety of physical activities; learning places in the playground that include maps, mazes, and sight words; and natural gardens and green areas for both aesthetic and pedagogical purposes. Developmentally appropriate play equipment, art exhibit spaces, and design for safety and accessibility so that all can enjoy the setting, also contribute to the creation of a design theme that reflects the local culture. Symbolic interactionists potentially offer the landscape designer greater understanding of designed spaces and their symbolic meanings for self and the generalized other. 


\section{Designing Work Places}

As previously discussed, symbolic interaction theory suggests that designed physical environment can represent the generalized other and assist in communicating shared symbols, and, therefore, influence users. Thomas Gieryn (2002b) has shown how architectural layout impacts the interaction among working scientists and ultimately their scientific performance. He reports that (1) face-to-face communication drops dramatically as the distance between their work places increase, and (2) scientific performance increases with the frequency of chance encounters, even when the workers are on different projects or work teams. Based on these findings, it would appear that incorporating central meeting places, such as mailrooms, conference areas, central gardens or photocopying areas, or designing movable walls, desks, and chairs might well increase the possibilities for interaction and improved performance in terms of new ideas, products, and services among certain types of workers (Allen 1977).

Similarly, Townsend (2000) illustrates how building design can influence workers' personal pleasure and therefore their work creativity. She argues that a joyful environment where workers can express their own energy can be created with three combined elements: (1) architectural designs that are symbolic of openness, freedom, and exchange of ideas; (2) managers who encourage open communication and innovation; and (3) co-workers who are cooperative and supportive. Thus, designed physical environment may be one of several factors that can promote a self-work role merger, or a situation where work becomes a primary site for the expression of the creative self.

The relationship between designed physical environment and worker creativity is more complex that what might first appear. For example, in specific work environments, designs that promote chance encounters and therefore increased group discussion may be viewed as leading to greater worker creativity; however, a counterargument might be that designs that provide for privacy lead to greater worker creativity. A third view might be that for some workers, creativity is most encouraged in a combination of private and public spaces. It would be interesting to determine if specific workers are more likely to create their new ideas in private work spaces, or if these same workers are more likely to create new ideas in public work spaces and then return to their private work spaces for further expansion of ideas-and then proceed to test these new ideas in public workspaces with responsive audiences. The research methods used by symbolic interactionists (e.g., in-depth observation and personal interviewing) would likely give us an excellent understanding of the role of public and private work space and the creative process of the worker.

Symbolic interactionists could also contribute to the understanding of our workforce as it becomes even more diverse in terms of gender, age, race, and ethnicity. Each group is likely to bring forth a somewhat different set of personal meanings for work and the self-work relationship. Kupritz (2000) has noted that as our workforce becomes older (the median age will be 41 years in 2005, as compared to 35 years in 1993), organizations will need to make adjustments in physical design to satisfy these 
workers' needs and expectations. Kupritz found that older and middle-age workers prefer their own personal work space; extra space for personal belongings; nearby conference rooms for small meetings; better lighting, walls, partitions, and doors that provide privacy to improve their concentration; and closer supervisor-worker proximity.

\section{Building Communities}

Symbolic interactionists would likely maintain that residents' positive meanings and emotions about their neighborhoods are vital if vibrant communities are to develop and flourish (Burns 2000). Interactionists would be ideally suited to conduct ethnographic work in communities, and perhaps to collaborate with "new urbanist" planners and architects to create more compelling and livable neighborhoods. For example, in light of problems such as city congestion, increased diversity in terms of racial, ethnic, and class differences, and physical fragmentation, residents might well reveal that they could benefit from territorial niches to establish a sense of place security and place identity. Alleys that have safe lighting and are without fences and other obstructions can provide a physical setting that encourages interaction and a sense of solidarity among community residents (Martin 1996). Other aspects of physical design could create greater opportunities for interaction, networking, sharing of symbols, cooperation, and stronger attachment to community. These include front and rear porches, layout of streets that encourage neighbor contacts rather than isolation, park-like spaces, wide sidewalks, placement of schools close to homes, local libraries, close-by community and childcare centers, adequate outdoor lighting for better safety, convenient transportation hubs, and easy access to service providers and businesses (Higgitt and Memken 2001).

Ethnic conclaves such as Chinatowns, little Saigons, and Irish, Italian, and Mexican neighborhoods have always been part of U.S. cities. Designers would be welladvised to respond as these and other ethnic communities form and grow. These enclaves allow immigrants to preserve their culture, collective memories, and personal identities; to ward off culture shock; and to transition slowly to a new social and cultural reality. Symbolic interactionists, community residents, and architects could well collaborate to create community designs that preserve these meanings, promote interaction, and allow expression of the ethnic self by designing spaces for religious practices, festivals, and community gatherings. Design features and landscapes could remind users of their original homelands by providing signs written in both native language and English, naming the enclave to reflect the immigrant's homeland, and building structures that are familiar and consistent with the norms and expectations of the immigrant's culture of origin ( Low et al. 2002, Mazumdar et al. 2000).

\section{Designing Retirement Homes}

The transition of retirees to retirement homes can be especially difficult. As a means to ease the transition, symbolic interactionists might well focus on how re- 
tirement home design can encourage positive memories and emotions. They might provide suggestions on how to incorporate the personal possessions of residents in the interior design, such as providing adequate space to display as well as touch heirlooms. Entry niches and exhibit areas, personalized space, and generous lighting for display would seem to be helpful (Boschetti 1995, Eshelman and Evans 2002).

Place attachment for retirees can be encouraged through the careful placement of physical structures. Placement of living units adjacent to each other, close to meeting hubs and dining facilities, near pedestrian path intersections and/or gardens or other natural areas would seemingly provide a greater chance for interaction, group identity, and emotional comfort (Sugihara and Evans 2000). Of primary importance, retirees should be consulted throughout the design process on how they feel about their treasured possessions and how their new homes should be designed to effect place attachment.

Still another consideration in designing retirement homes is the opportunity for recreational and physical activity. Retirees who have greater physical capability might benefit from tree-lined walking trails, walkable green areas, easy access to exercise equipment, and independent exercise. Older and less physically capable residents may need more motivational signs, organized group exercises, closely supervised exercise classes, and, of course, less physically demanding programs. Resident perceptions about the value of exercise and related physical barriers (such as poor lighting, fear for safety, uninteresting destinations, and unsafe foot paths) would be important to understand (Joseph and Zimring 2004). The assumption made is that well-designed exercise and recreation places are important not only for physical maintenance, but also a positive sense of place attachment, self, and self-efficacy.

\section{Creating Sacred Places}

An examination of the design of sacred places provides insight into the symbolic significance of these architectural forms and their linkages to a spiritual self. Watson and Kucko (2001) studied two highly acclaimed religious chapels in Arkansas. There, designers create a building-site relationship by merging the physical structures into a pristine natural landscape, especially using water and light to improve upon the natural setting. They also use lighting to enhance height, verticality, texture, patterns, and ornamentation; employ sound to enhance the emotions of users; situate parking and other distractions away from the chapel; and design in careful proportionality and with primary use of plane and solid shapes.

The design of sacred places is not confined to chapels and churches, as is the usual thinking, but can extend to other forms of architecture as well. Weller Architects, located in Albuquerque, New Mexico, consults with Native American tribal groups as they design and build their communities. They have found that many Native Americans view community not as just a place to live but as a sacred placea place that should have strong spiritual connections to the natural environment (Weller 2004). Symbolic interactionists, using their ethnographic methods of in- 
depth observation and interviewing to examine groups, would seem perfectly suited to assist in the design of sacred and other culturally appropriate communities.

\section{FINAL THOUGHTS}

As this discussion suggests, architecture is in a sense "us"-it both reflects and influences our thoughts, emotions, and actions. In light of the importance of designed physical environment, sociologists' general tendency to ignore it, or to consider it as either a given that is undeserving of our attention or as existing beyond the boundaries of appropriate domains of scholarly interest, is surprising. We should renew the tradition passed to us by classical sociologists such as Simmel (1950), Park (1915), Mead (1934), Goffman (1951, 1959, 1963), and Homans (1974), who granted designed physical forms their due importance. It is time for architectural sociology to capture our attention once again, and for sociologists to collaborate with environmental psychologists and architectural anthropologists to learn from and contribute to the study of designed physical environments and their implications. Symbolic interaction theory and its methods could make an important contribution toward this effort.

Acknowledgments: The primary author would like to give special thanks to colleagues Simon Gottschalk, Robert Futrell, and Susan Thompson for their many insights and suggestions. Craig Galati and Raymond Lucchesi (Lucchesi-Galati Architects), colleagues Frederick Preston, and Ralph Stern (UNLV School of Architecture) were also ongoing sources of encouragement in writing this paper.

\section{REFERENCES}

Abel, Chris. 2000. Architecture as Identity in Architecture: Responses to Cultural and Technological Change. Oxford: Architectural Press.

Alexander, Christopher. 1979. The Timeless Way of Building. New York: Oxford University Press.

Allen, Thomas J. 1977. Managing the Flow of Technology. Cambridge, MA: MIT Press.

Amor, Cherif. 2004. "Semantics of the Built Environment: Arab American Muslims' Home Interiors." Pp. 8-15 in Proceedings of the 35th Annual Conference of the Environmental Design Research Association (EDRA), edited by D. Miller and J. A. Wise. Edmond, OK: EDRA.

Ankerl, Guy. 1981. Experimental Sociology of Architecture: A Guide to Theory, Research, and Literature. The Hague: Mouton.

Appleyard, Donald. 1979. "Home." Architectural Association Quarterly 11:4-20.

Ashley, David and David Orenstein. 1998. Sociological Theory: Classical Statements. Boston: Allyn and Bacon.

Barthes, Roland 1986. "Semiology and the Urban." Pp. 87-98 in The City and the Sign, edited by M. Gottdeiner and A. Lagopoulos. New York: Columbia University Press.

Baudrillard, Jean. 1994. Simulacra and Simulation, translated by S. Faria Glaser. Ann Arbor: University of Michigan Press.

Baudrillard, Jean and Jean Nouvel. 2003. The Singular Objects of Architecture. Minneapolis: University of Minnesota Press. 
Blumer, Herbert. 1969. Symbolic Interactionism: Perspective and Method. Englewood Cliffs, NJ: Prentice Hall.

Boschetti, Margaret A. 1995. "Attachment to Personal Possessions: An Interpretive Study of the Older Person's Experience.” Journal of Interior Design 21:1-12.

Bourdieu, Pierre. 1977. Outline of a Theory of Practice. Cambridge: Cambridge University Press.

. 1990. The Logic of Practice. Stanford, CA: Stanford University Press.

Brink, Lois and Bambi Yost. 2004. "Tranforming Inner-City School Grounds: Lessons from Learning landscapes." Children, Youth and Environments 14:209-32.

Broadbent, Geoffrey. 1980. "Architects and Their Symbols." Pp. 10-28 in Built Environment, vol. 6, edited by Geoffrey Broadbent. New York: John Wiley and Sons.

Brown, Jonathan D. 1998. The Self. Boston: McGraw-Hill.

Bugni, Valerie and Ronald W. Smith. 2002a, October. "Architectural Sociology Resources." Connections Newsletter, American Institute of Architects, Las Vegas, Nevada.

— 2002b, May. "Getting to a Better Future through Architecture and Sociology." Connections Newsletter, American Institute of Architects, Las Vegas, Nevada.

Burns, Ausra. 2000. "Emotion and Urban Experience: Implications for Design." Design Issues 16: $67-69$.

Carroll, Donald. 2000. Mary's House. London: Veritas Books.

Catton, William R. and Riley E. Dunlap. 1978. "Environmental Sociology: A New Paradigm.” The American Sociologist 13:41-49.

Churchill, Winston S. 1924. Address to the Architectural Association at the annual distribution of prizes in 1924. Reprinted Architectural Association Quarterly 5:44-46.

Cohen, Joseph. 1989. "About Steaks Liking to Be Eaten: The Conflicting Views of Symbolic Interactionism and Talcott Parsons Concerning the Nature of Relations between Persons and Nonhuman Objects." Symbolic Interaction 12:191-213.

Cooley, Charles Horton. 1902. Human Nature and the Social Order. New York: Charles Scribner's Sons.

Cranz, Galen. 1989. The Politics of Park Design: A History of Urban Parks in America. Cambridge, MA: MIT Press. .1998. The Chair: Rethinking Culture, Body, and Design. New York:W.W. Norton.

Davis, Howard. 1999. The Culture of Building. New York: Oxford University Press.

Day, Christopher. 1990. Places of the Soul: Architecture and Environmental Design as a Healing Art. Wellingborough, UK: Aquarian/Thorsons.

Dubois, William D. 2001. "Design and Human Behavior: Sociology of Architecture." Pp. 30-45 in Applying Sociology: Making a Better World, edited by W. DuBois and R. D. Wright. Boston, MA: Allyn and Bacon.

Duffy, Francis and Les Hutton. 1998. Architectural Knowledge. London: Routledge.

Durkheim, Emile. [1915] 1976. The Elementary Forms of Religious Life. London: George Allen and Unwin.

Eco, U. 1972. "The Componential Analysis of the Architectural Sign/Column," Semiotica 5:97-117.

Eshelman, Paul E. and Gary W. Evans. 2002. "Home Again: Environmental Predictors of Place attachment and Self-esteem Among Retirement Community Residents." Journal of Interior Design 28:3-9.

Forty, Adrian. 1986. Objects of Desire. New York: Pantheon Books.

Foucault, Michel 1979. Discipline and Punish: The Birth of the Prison. New York: Vintage.

Giddens, Anthony. 1990. Consequences of Modernity. Stanford, CA: Stanford University Press.

Gieryn, Thomas F. 2000. "A Place for Space in Sociology.” Pp. 263-96 in Annual Review of Sociology, vol. 26, edited by K. Cook and J. Hagen. Palo Alto, CA: Annual Reviews Inc. .2002a. "Three Truth-Spots." Journal of History of the Behavioral Sciences 38:113-32. 2002b. "What Buildings Do," Theory and Society 31:35-74.

Goffman, Erving. 1951. "Symbols of Class Status." British Journal of Sociology 2:294-304.

. 1959. The Presentation of Self in Everyday Life. New York: Doubleday. . 1963. Stigma: Notes on the Management of Spoiled Identity. Englewood Cliffs, NJ: Prentice Hall. 
Gottdeiner, Mark and Ray Hutchison. 2000. The New Urban Sociology. Boston: McGraw Hill.

Gutman, Robert. 1985. The Design of American Housing: A Reappraisal of the Architect's Role. New York: Publishing Center for Cultural Resources. .1988. Architectural Practice: A Critical View. New York: Princeton Architectural Press.

Habermas, Jurgen. 1989. The New Conservativism: Cultural Criticism and the Historians' Debate, translated by S. Weber Nicholsen. Cambridge: MIT Press.

Hannigan, John A. 1995. Environmental Sociology: A Social Constructionist Perspective. New York: Routledge.

Harvey, David. 1989. Conditions of Postmodernity: An Enquiry into the Orgins of Cultural Change. Cambridge, MA: Blackwell.

Hatch, Mary Jo. 1997. Organization Theory. New York: Oxford University Press.

Heismath, Clovis. 1977. Behavioral Architecture: Toward an Accountable Design Process. New York: McGraw-Hill.

Henderson, Susan R. 1997. "New Buildings Create New People: The Pavillion Schools of the Weimar Frankfurt as a Model of Pedagogical Reform." Design Issues 13:27-38.

Higgit, Nancy C. and Jean A. Memken. 2001. "Understanding Neighborhoods." Housing and Society 28:29-46.

Homans, George. 1974. Social Behavior: Its Elementary Forms. New York: Harcourt, Brace, Jovanovich.

James, William. 1890. The Principles of Psychology. Vol. 1. New York: Holt.

Jameson, Federic. 1991. Postmodernism, or, The Cultural Logic of Late Capitalism: Post-Contemporary Interventions. Durham, NC: Duke University Press.

Jencks, Charles A. 1977. Language of Post-Modern Architecture. London: Academy Editions.

Johnson, Lauri Macmillan. 2004. "Design Intervention in the Sonoran Desert-The Results of a Landscape Architecture Studio Design Project." Pp. 147-48 in Proceedings of the 35th Annual Conference of the Environmental Design Research Association (EDRA), edited by D. Miller and J. A. Wise. Edmond, OK: EDRA.

Jones, Bernie. 1984. "Doing Sociology with the Design Professions." Clinical Sociological Review 2:109-19.

Joseph, Anjali and Craig Zimring. 2004. "Activity Friendly Environments for Older Adults: A Critical Review of the Literature." P. 121 in Proceedings of the 35th Annual Conference of the Environmental Design Research Association (EDRA), edited by D. Miller and J. A. Wise. Edmond, OK: EDRA.

Knappert, Carl. 2002. "Photographs, Skeuomorphs, and Marionettes: Some Thoughts on Mind, Agency, and Object." Journal of Material Culture 7:97-117.

Kupritz, Virginia W. 2000. "The Role of the Physical Environment in Maximizing Opportunities in the Workforce." Journal of Industrial Teacher Education 372:66-88.

Lawrence, Denise L. and Setha M. Low. 1990. "The Built Environment and Spatial Form.” Annual Review of Anthropology 19:453-505.

Levin, Thomas Y, Ursula Frohne, and Peter Weibel. 2002. CTRL Space: Rhetorics of Surveillance from Bentham to Big Brother. Cambridge, MA: MIT Press.

Low, Setha M., Dana Taplin, Suzanne Scheld, and Tracy Fisher. 2002. "Recapturing Erased Histories: Ethnicity, Design, and Cultural Representation in a Study of Independence National Historical Park." Journal of Architectural and Planning Research 19:282-99.

Marcus, Clare Cooper. 1995. House as a Mirror of Self: Exploring the Deeper Meaning of Home. Berkeley, CA: Conari Press.

Martin, Michael. 1996. "Back Alley as Community Landscape.” Landscape Journal 15:138-53.

Mazumdar, Sanjoy, Shampa Mazundar, Faye Docuyanan, and Colette Marie McLauglin. 2000. "Creating a Sense of Place: The Vietnamese-Americans and Little Saigon." Journal of Environmental Psychology 20:319-33.

McCarthy, E. Doyle. 1984. "Toward a Sociology of the Physical World: George Herbert Mead on Physical Objects." Studies in Symbolic Interaction 5:105-21.

Mead, George Herbert. [1932] 2002. The Philosophy of the Present. Amherst, NY: Prometheus Books. 
1934. Mind, Self, and Society. Chicago: The University of Chicago Press.

Milligan, Melinda J. 1998. "Interactional Past and Potential: The Social Construction of Place Attachment." Symbolic Interaction 21:1-33.

2003. "Displacement and Identity Discontinuity: The Role of Nostalgia in Establishing New Identity Categories." Symbolic Interaction 263:381-403.

Murphy, Raymond. 2001. "Sociology as If Nature Did Not Matter: An Ecological Critique." Pp. 27-42 in The Environment and Society Reader, edited by R. S. Frey. Needham Heights, MA: Allyn and Bacon.

Olmsted, Frederick and S. B. Sutton, eds. 1979. Civilizing American Cities: A Selection of Frederick Law Olmsted's Writings on City Landscape. Cambridge, MA: MIT Press.

Owens, Erica. 2004, February. "I Hate This F*\#ing Computer: Theorizing How and When Objects Become Actors." Paper presented at Couch-Stone Symposium, Society for the Study of Symbolic Interaction, Vancouver, Canada.

Park, Robert. 1915. "The City: Suggestions for the Investigation of Human Behavior in an Urban Environment.” American Journal of Sociology 20:577-612.

Prior, Lindsay. 1993. The Social Organization of Mental Illness. London: Sage.

Reise, Walther. 1950. "Philippe Pinel (1745-1826), His Views on Human Nature and Disease, His Medical Thought." Journal of Nervous and Mental Disease 114:313-23.

Rendell, Jane, Barbara Penner, and Iain Borden, eds. 2000. Gender Space Architecture: An Interdisciplinary Introduction. London: Routledge.

Riggins, Stephen Harold. 1990. "The Power of Things: The Role of Domestic Objects in the Presentation of Self." Pp. 341-67 in Beyond Goffman: Studies on Communication, Institution, and Social Interaction. Berlin: Mouton de Gruyter.

Shields, Rob. 1992. Lifestyle Shopping: The Subject of Consumption. London: Routledge.

Simmel, Georg. [1917] 1950. "The Metropolis and Mental Life," Pp. 409-24 in The Sociology of Georg Simmel, edited by K. Wolff. Glencoe, IL: Free Press.

Smith, Ronald and Valerie Bugni. 2002. "Designed Physical Environment as Related to Selves, Symbols, and Social Reality: A Proposal for a Paradigm Shift for Architecture.” Humanity and Society 26:293-311.

Sommer, Robert. 1969. Personal Space: The Behavioral Basis of Design. Englewood Cliffs, NJ: Prentice-Hall.

- 1974. Tight Spaces: Hard Architecture and How to Humanize It. Englewood Cliffs, NJ: Prentice-Hall.

1983. Social Design: Creating Buildings with People in Mind. Englewood Cliffs, NJ: Prentice-Hall.

Sorkin, Michael. 2003. Starting from Zero: Reconstructing Downtown New York. New York: Routledge.

Spain, Daphne 1992. Gendered Space. Chapel Hill: University of North Carolina Press.

Steele, Fritz. 1973. Physical Settings and Organizational Development. Reading, MA: AddisonWesley. 1981. The Sense of Place. Boston, MA: CBI.

1983. Making and Managing High-Quality Workplaces. New York: Teachers College Press.

Sugihara, Shiho and Gary W. Evans. 2000. "Place Attachment and Social Support at Continuing Care Retirement Communities." Environment and Behavior 32:400-409.

Townsend, Jackie. 2000. "Creativity in the Workplace." Pp. 18-28 in Creating the Productive Workplace, edited by D. Clements-Croome. London: Taylor and Francis.

Turner, John F. C. 1976. Housing by People: Towards Autonomy in Building Environments. London: Marion Boyars.

Watson, Stephanie A. and Jane K. Kucko. 2001. "Thorncrown and the Mildred B. Cooper Chapels: Sacred Structures Designed by Fay Jones." Journal of Interior Design 27:14-25.

Weller, Louis 2004. "The Spirit of Place in Contemporary Native American Architecture." Pp. 3-4 in Proceedings of the 35th Annual Conference of the Environmental Design Research Association (EDRA), edited by D. Miller and J. A. Wise. Edmond, OK: EDRA. 
Werlen, Benno. 1993. Society, Action and Space: An Alternative Human Geography. London: Routledge.

Wilson, Chris. 1997. The Myth of Santa Fe: Creating a Modern Regional Tradition. Albuquerque: University of New Mexico Press.

Wolfe, Tom. 1981. From Bauhaus to Our House. New York: Simon and Schuster.

Zeisel, John. 1975. Sociology and Architectural Design. New York: Russell Sage Foundation. . 1977. Low Rise Housing for Older People: Behavioral Criteria for Design. Washington, DC: Department of Housing and Urban Development, Office of Policy Development and Research.

1984. Inquiry by Design: Tools for Environment-Behavior Research. New York: Cambridge University Press. 